\title{
Recent discovery of a unique Paleolithic industry from the Yumidong Cave site in the Three Gorges region of Yangtze River, southwest China
}

\author{
Guangbiao Wei ${ }^{a}$, Wanbo Huang ${ }^{a, b}$, Eric Bö̈da ${ }^{c}$, Hubert Forestier ${ }^{d}$, Cunding He ${ }^{a}$, \\ Shaokun Chen ${ }^{a, b, g}$, Jianxin Zhao ${ }^{e}$, Yinghua Li ${ }^{c, f} *$, Yamei Hou ${ }^{g}$, Libo Pang $^{a}$, Yan Wu ${ }^{a}$
}

${ }^{a}$ Chongqing Three Gorges Institute of Paleoanthropology, China Three Gorges Museum, Chongqing 400015, China

${ }^{b}$ Institute of Vertebrate Paleontology and Paleoanthropology, Chinese Academy of Sciences, Beijing 100044, China

${ }^{c}$ UMR 7041 CNRS ArSCAN, équipe AnTET, université Paris Ouest-Nanterre La Défense, 21, allée de l’Université, 92023 Nanterre cedex, France

${ }^{\mathrm{d} I n s t i t u t ~ d e ~ P a l e ́ o n t o l o g i e ~ H u m a i n e, ~ U M R ~} 7194$ CNRS-MNHN, 1, René Panhard, 75013 Paris, France

${ }^{\mathrm{e}}$ Radiogenic Isotope Laboratory, Centre for Microscopy and Microanalysis, University of Queensland, Brisbane, QLD 4072, Australia

${ }^{\mathrm{f}}$ School of History, Wuhan University, Wuhan ,430072, China

g Key Laboratory of Vertebrate Evolution and Human Origin of Chinese Academy of Sciences, Institute of Vertebrate Paleontology and Paleoanthropology, Chinese Academy of Sciences, Beijing, 100044 China

\section{Abstract}

The Three Gorges of Yangtze River, southwest China, abundant in human and faunal fossils, and lithic artifacts, represents an important site complex for understanding hominin dispersion and adaptations during the Pleistocene. The Yumidong Cave is a newly-discovered Paleolithic site in this region which yielded a large number of animal fossils and lithic artifacts. U-Th dating in conjunction with biostratigraphic analysis indicated that the archaeological remains were deposited during a long sequence from ca. 400 to $8 \mathrm{ka}$ (Middle Pleistocene to Holocene).

*Corresponding author:

E-mail addresses: elephantfossil@aliyun.com (G. Wei), lyhfrance2005@yahoo.fr (Y. Li) 
Lithic technological analysis indicated an original material shaped on massive limestone blocks with chaîne opératoire consisted of selection, shaping and retouching. The volumetric structures of selected blanks are regrouped into three categories : structures with bevel(s), trihedral structure and convergent ones. The outline of cutting-edge is predonimated by denticulate ones, followed by saw-like ones, rostrum, convergent with a denticulate edge and beaked ones. Despite showing nothing in common with Europe, Africa, the Near East and even the Indian Subcontinent and northern China, the lithic assemblage of the Yumidong Cave exhibits a strong coherence and presents more similarity to mainland Southeast Asia with heavy, angular and massive stone tools made on pebble, cobble and without the Levallois, Discoid, and blade/bladelet phenomenon. The lithic assemblage of Yumidong Cave may represent material clues of a potential local technological center of origin in unique technical world of Central-South China and its uniqueness would be understandable as the result of a successful adaptation of hominids to a specific environment. Yumidong lithic material deconstructs the existing paradigm for a long period of time and presents new ideas and new facts for the technic evolution in South China.

Keywords: Middle to Late Pleistocene, Paleolithic site, Lithic technology, Cognition, Three Gorges, China

\section{Introduction}

The Three Gorges region of the Yangtze River, southwest China, is well known for many discoveries of unique hominin fossils, faunal remains and various lithic artifacts that contribute to reopening the scientific dialogue about hominin dispersion and adaptations during the Pleistocene (Pei et al., 2013). Chinese Paleolithic research in the Three Gorges region demonstrates the importance of this area situated between the upper and middle reaches of the Yangtze River for the study of faunal dispersal and environmental change. In particular, the Ailuropoda-Stegodon faunal complex, representative of a subtropical forest environment, has received much attention. It was commonly accepted that the Qinling Mountain Range - Huai River Line in central China was the dividing line between the subtropical Gigantopithecus fauna of the Plio-Pleistocene and the Ailuropoda-Stegodon complex of the Middle to Late Pleistocene of South China and the Palearctic, temperate 
Nihewan fauna of North China (Aigner, 1981; Han and Xu, 1989).

During the past few decades, a large number of Paleolithic open-air sites (Yandunbao, Gaojiazhen, Fanjiahe, Ranjialukou, Chibaling, Jingshuiwan, Zaoziping) and cave sites (Zhongjiawan, Xinglongdong, Migongdong, Dashidong, etc.) were discovered, mapped and excavated along the Yangtze River. The lithic artifacts, animal fossils and some human remains were recovered and changed our knowledge of the prehistoric data. These findings include: Zhongjiawan Cave in Changyang County yielding one hominin upper jaw fragment and one lower premolar (Chia, 1957); Sunjiadong Cave in Zigui County with some mammalian fossils and lithic artifacts collected from the sediments (Dong, 1998); Xinglongdong Cave in Fengjie County dated between $118 \pm 7$ ka and $154 \pm 9$ ka with hominid fossils, archaeological and paleontological remains associated (Huang and Xu, 2002; Gao et al., 2004) ; Dashidong Cave in Wushan County with bone and teeth of an Homo sapiens and stone tools from the Late Pleistocene to Holocene (Guangbiao Wei et al., submitted for publication) ; Migongdong Cave in Wushan County where two partial modern Homo sapiens fossil bones, fauna and stone tools dated to $13,150 \pm 190$ BP were recovered (Huang et al., 2000).

Yumidong Cave represents a new discovery of a Paleolithic site in the Three Gorges Region of the Yangtze River. During excavation from 2011 to 2013, about 3000 mammalian fossils and more than 3000 lithic artifacts were unearthed. The mammalian fossils indicate that the sediments yielding Paleolithic remains were deposited during the Middle and Late Pleistocene. The lithic assemblage of Yumidong Cave exhibits a salient technological feature as yet unknown in any other sites in central, western and southern China. In this regional context, abundant in prehistoric remains and extremely interesting for research on hominin occupation and cultural adaptations, the Yumidong Cave site will enrich current discussion about the originality of Paleolithic technology from the Three Gorges region, essentially considered to be an "Oldowan-like industry" (Mode1) comprised of cores, whole flakes, fragments, and chunks as well as a low percentage of retouched tools (Pei et al., 2013). Given that both archaic and modern Homo sapiens identified in some of the regional cave deposits are likely the hominins responsible for the production of the lithic artifacts, the discovery of Yumidong Cave would raise new questions for their implications in technological patterning 
in South China. Yumidong Cave, which provides a long archaeological sequence with the association of lithic artifacts and animal remains, offers the possibility to discuss technical evolution with regard to environmental determinism from the Middle to Late Pleistocene. Yumidong data will also enrich the Chinese Paleolithic record and contribute to paleoanthropological debates across broader regional and/or temporal facies.

\section{Site background}

\subsection{Location and geological setting of the site}

The Paleolithic site of Yumidong Cave is located in Xiaoying Village, Miaoyu Town, Wushan County of Chongqing Municipality $\left(30^{\circ} 50^{\prime} 44.4^{\prime \prime} \mathrm{N}, 109^{\circ} 38^{\prime} 09.2^{\prime \prime} \mathrm{E}\right)$ (Fig. 1). It is situated to the south of the Yangtze River, in the hinterland of the Three Gorges, and $1100 \mathrm{~m}$ above sea level. This site is about $4 \mathrm{~km}$ southwest of the Longgupo site and the dissolution basin of Miaoyu which is situated on the west end of the Wushan Mountains.

The Yumidong site is a horizontal karst cave formed in the bedded limestone of the Triassic Jialingjiang Formation. It faces southwest, opening onto an esplanade. A vertical skylight of $3 \mathrm{~m}$ in diameter developed $30 \mathrm{~m}$ from the entrance, providing favorable air circulation and light (Fig. 2).

The Yumidong site was discovered in autumn 2004. The deposits were extensively distributed and well preserved in the cave. Preliminary investigation indicated that the deposits containing Paleolithic material covered an area of more than $1000 \mathrm{~m}^{2}$. In 2011-2013, one test pit and two formal excavations were undertaken by the Chongqing Three Gorges Institute of Paleoanthropology, exposing an area of $100 \mathrm{~m}^{2}$. A large quantity of lithic artifacts $(\mathrm{N}>3000)$ and mammalian fossils $(\mathrm{N}>3000)$ were recovered in stratigraphic context.

\subsection{Stratigraphy}

The excavation zone is comprised of eight $5 \times 5 \mathrm{~m}$ grids (Fig. 2). The stratigraphy is represented by excavation units $\mathrm{T} 3$ and T4, in which the deposits are respectively $5 \mathrm{~m}$ and 4 $\mathrm{m}$ in thickness, without reaching the bedrock of the cave. The Paleolithic remains were found from the top of Layer 2 to the bottom of the excavation pits. The stratigraphy was differentiated essentially according to texture and color of sediments, in conjunction with 
artificially-defined stratigraphic units (every $10 \mathrm{~cm}$ ). During excavation much attention was paid to the attitude of calcareous plates which may suggest climatic change (dry or humid).

The cave deposits are mainly composed of breccia and brown karst sandy clay interlaid in some parts with carbonate bands. The breccia is more commonly predominated by slightly weathered limestone. Their orientation and inclination angle indicates that they had probably been transported from the entrance by seasonal flooding and then deposited in the chamber. The breccia $(30 \times 50 \mathrm{~cm})$ without evident weathering could come from the walls and the top of the cavern which collapsed at some time, while the slightly-weathered gravel-sized limestone fragments would possibly come from outside of the cave.

The stratigraphic sequence of Yumidong Cave can be represented by excavation unit T4 from top to bottom (Fig. 3). Excluding the surface soil composed of clay and silty soil with breccia, which is loose and contains modern carbonate sediments in some parts, the stratigraphic sequence was divided into five layers.

Layer 1. Brown-grey (partially brown-black) sandy clay (10-15 cm in thickness), loose in texture, accompanied by some breccia on limestone, yielding a number of small mammalian fossils.

Layer 2-1. Brown sandy clay (30-35 $\mathrm{cm}$ in thickness) with some breccia, yielding many small mammalian fossils.

Layer 2-2. Brown sandy clay (120-155 cm in thickness) with some badly sorted breccia with maximum length of $90 \mathrm{~cm}$ and minimum length of $1-5 \mathrm{~cm}$, showing livid cortex. The deposits in the west part are lower than those in the east, suggesting an effect of seasonal flooding. Meanwhile, the roof collapsed due to alluvial erosion, depositing breccia in the sediments. This layer yielded a number of lithic artifacts and mammalian fossils.

Layer 3. Light brown-grey sandy clay accompanied by some well-sorted breccia (mostly $3-5 \mathrm{~cm}$ in length). This layer contains some carbonated cementation, hard in texture and yielded a small number of lithic artifacts and mammalian fossils.

Layer 4. Brown sandy clay accompanied by breccia and silty lens. This layer is largely composed of sticky clay, which showed rimous texture after drying. Some lithic artifacts and mammalian fossils were recovered. 
Layer 5. Light grey sandy clay accompanied by small breccia, yielding a small quantity of lithic artifacts and mammalian fossils.

\subsection{Unearthed remains}

About 3000 mammalian fossils were collected in situ from the excavation units, composed of 46 genera and 53 species, including the following genera and species: Anourosorex squamipes, Sorex sp., Soriculus leucops, Soriculus sp., Blarinella quadraticauda, Chodsigoa salenskii, Scaptonyx fusicaudus, Euroscaptor longirestris, Parascaptor leucurus, Rhinolophus pearsoni, Myotis sp., Apodemus latronum, Niviventer andersoni, N. confucianus, N. excelsior, Rattus norvegicus, Vernaya fulva, Eothenomys custos, Eothenomys sp., Hystrix subcristata, H. kiangshanensis, Rhizomys sinensis, Tscheskia triton, Typhlomys cinereus, Petaurista xanthotis, Pteromys volans, Trogopterus xanthipes, Belomys pearsoni, Hylobates sp., Macaca sp., Canis sp., Panthera tigris, Felis sp., ?Homotherium sp., Arctonyx collaris, Paguma larvata, Crocuta crocuta, Ailuropoda melanoleuca baconi, Ursus thibetanus, Stegodon orientalis, Stegodon sp., Stephanorhinus sp., Dicerorhinus sp., Megatapirus augustus, Equus sp., Sus scrofa, Muntiacus muntjak, Cervus unicolor, Cervus sp., Moschus sp., Capricornis sumatraensis, Bubalus sp. and Bibos sp. (Fig.4).

The mammal assemblage of Yumidong is equivalent to the typical Ailuropoda-Stegodon fauna (sensu stricto) of southern China. The co-occurrence of Ailuropoda melanoleuca baconi, Stegodon orientalis, Megatapirus augustus and Stephanorhinus sp. place the excavated deposits of Yumidong site in the Middle and Late Pleistocene.

More than 3000 lithic artifacts were found in stratigraphic context. The specimens reported in this paper were mostly recovered in seasons of 2011-2012 from Layers 2 to 5 in excavation units T3 and T4. In addition, a small number of bone, tooth, and antler artifacts were also discovered in 2013 from Layer 2, which were produced mainly on limb bones of large mammals, ivories and tooth plates of Stegodon, antlers of deer, and incisors of deer and cattle. These artifacts were all found in primary context and exhibited clear differences from extant species by their significant degree of fossilization and primitive morphological traits. 


\subsection{Dating}

Chronometric dating analysis for the layers yielding Paleolithic remains (Layers 2, 3 and 4) was carried out by using the U-Th dating method in the Radiogenic Isotope Laboratory of the University of Queensland, Australia.

Five fossil tooth and calcite vein samples drilled from 4 hand specimens were submitted to The Radiogenic Isotope Facility, School of Earth Sciences, the University of Queensland for $\mathrm{U} / \mathrm{Th}$ dating on a $\mathrm{Nu}$ Plasma multi-collector inductively coupled plasma mass spectrometer (MC-ICP-MS). Each sample of 10-100mg was spiked with a ${ }^{229} \mathrm{Th}^{-233} \mathrm{U}$ mixed tracer and dissolved in double-distilled nitric acid. After full digestion, a few drops of $\mathrm{H}_{2} \mathrm{O}_{2}$ were added to decompose any trace amount of organic matter and to ensure complete tracer-sample mixing. $U$ and Th were purified using a modified ion-exchange method described in detail in Zhao et al. (2001) and Clark et al. (2012). After chemical separation, the Th aliquot was mixed with a certain percentage of $U$ aliquot and the mixture was diluted to $3-\mathrm{ml}$ in $2 \% \mathrm{HNO}_{3}$. The percentage of $\mathrm{U}$ needed for making the mixed solution depends on the amount of $U$ in the sample. Generally a $U$ concentration of $\sim 10 \mathrm{ppb}$ or less in the final 3-ml solution is targeted, which was calculated based on pre-screened signals from a more dilute U-Th solution. The U-Th mixed solution was then injected into the MC-ICP-MS through a DSN-100 desolvation system with an uptake rate of around $0.12 \mathrm{ml}$ per minute. U-Th isotopic ratio measurement was performed fully automatically on the $\mathrm{Nu}$ Plasma MC-ICP-MS following the analytical protocol described in Zhou et al. (2011) and Roff et al. (2013). After MC-ICP-MS measurements, U-Th ages were calculated using Isoplot/EX 3.0 Program (Ludwig, 2003). The results indicated that the Paleolithic remains of the Yumidong Cave were deposited from the Middle Pleistocene to Holocene (400-8 ka) (Table 1) from top of Layer 2 to bottom of Layer 5.

\section{Lithic technology}

Technological analysis was conducted on 116 retouched artifacts obtained in the 2010/2011 excavation season, from Layers 2, 3 and 4. Among these artifacts, 75\% possess precise stratigraphic attribution and $25 \%$ derive from the three layers without distinction. As 
the distribution of the different technique types of artifacts was identical within these three layers, they were analyzed as a whole.

\subsection{Origin and availability of raw materials}

The raw materials were mostly Triassic limestone which could be found at the periphery of the site. They were homogeneous except for natural fissuring created by compression. The raw materials were distributed near the site in the form of plates with different sizes and volumetric structure, which affected hominid technical behaviors by reinforcing the selection of tool blanks. As a result, a number of blocks were taken into the site only for shaping and/or retouch. Some unretouched flakes were also introduced into the site as tool blanks.

Two-thirds of the lithic tools unearthed from the Yumidong site were made on plates and made through shaping and retouch. One-third was made on flakes using retouch. The deposition dynamics in the cave attest to an interstratification between clay of karst origin and limestone fragments collapsed from the ceiling of cave because of weathering. But no evidence indicates post-depositional disturbance which could support a natural hypothesis for such shaping and retouch. Although in some cases alteration similar to retouch can be present on two faces of a cutting-edge, this is not the case for the Yumidong site, where retouch removal scars are always present on one side of a cutting-edge, except for a few pieces with alternate retouch in order to create a saw-like cutting-edge.

\subsection{Operative schemes of lithic production}

The tools were classified into 13 volumetric types, which were made on plaquettes, fragments of plaquettes and flakes (Fig. 5). All these types were accomplished through two technical processes: selection, and façonnage/shaping. The surfaces constituting the cutting-edge of all types were either natural or artificial (positive and negative removal scars). These types could be regrouped into three categories based on their volumetric structures (Table 2). Category A (types 1 to 9) is characterized by a structure with bevel(s) in the form of a mirror. Category B (types 10 to 12) contains a transformative part which was accomplished through trihedral conception. Category $\mathrm{C}$ is composed of tools with convergent morphology and with a volumetric structure different from the others. 


\subsubsection{Category A- Structure with bevel(s)}

Each type of tool in this category is oriented and described according to three faces: sagittal, transversal and frontal (Fig. 6).

Type $1(\mathrm{~N}=11)$ : volume of a simple bevel, presenting trapezoidal sagittal face, and rectangular transversal and frontal faces. The functional axis of the tool may be twice as long as it is wide. Some variability is present in tool thickness and form of the frontal face (Fig. 7).

Type 2 (N=8): volume of two opposite bevels with overall parallelepipedal form, presenting rhombic sagittal face, quadrangular transversal face and quadrate frontal face (Fig. 8). Some variability is present tool thickness.

Type $3(\mathrm{~N}=7)$ : volume of two opposite bevels with overall parallelepipedal form, presenting parallelogrammic sagittal face, rectangular transversal and frontal faces. Some variability is seen in tool thickness and in the dimensions of the parallelepiped.

Type $4(\mathrm{~N}=4)$ : volume of two opposite bevels with overall parallelepipedal form, presenting parallelogrammic sagittal face, rectangular transversal and frontal faces (Fig. 9). Some variability is present in tool thickness. The functional axis of the tool is twice as wide as it is long.

Type $5(\mathrm{~N}=6)$ : volume of simple bevel with triangular frontal face, trapezoidal sagittal face and quadrangular transversal face.

Type $6(\mathrm{~N}=11)$ : This type is a variant of type 5. The length of tool is equal to that of the surface constituting the bevel. The sagittal face is triangular, the frontal face trapezoidal and the transversal face quadrangular.

Type $7(\mathrm{~N}=2)$ : The length of tool is equal to that of the surface constituting the bevel which has a triangular sagittal face, trapezoidal frontal face and quadrangular transversal face. Some variability is present in tool thickness and morphology of the frontal face.

Type $8(\mathrm{~N}=15)$ : volume of simple bevel with overall parallelepipedal form, presenting trapezoidal sagittal, transversal and frontal faces. Minor variability was identified in tool thickness of tool and dimensions of the parallelogram. 
Type $9(\mathrm{~N}=11)$ : volume with overall prismoid form, presenting triangular sagittal face, rectangular transversal and frontal faces. The functional axis of tool is twice as wide as it is long.

\subsubsection{Category $\mathrm{B}$ - Trihedral structure}

Type $10(\mathrm{~N}=7)$ : volume with morphology of an asymmetric trihedron. The sagittal, transversal and frontal faces are all triangular.

Type $11(\mathrm{~N}=3)$ : volume with symmetric trihedron. The sagittal, transversal and frontal faces are all triangular.

Type $12(\mathrm{~N}=7)$ : volume with trapezoidal sagittal face, rectangular transversal face and triangular frontal face. Minor variability is present in tool dimensions and morphology.

\subsubsection{Category $\mathrm{C}$-Convergent tools}

A total of ten pieces were regrouped into this category. The dimensions of blanks varies, the largest of which is more than 20 centimeters long following the morphological axis, but is also three to four centimeters thick (Figs. 10 and 11). Some tools are extremely small in size (Fig. 12). As for tools made on large plaquettes or large flake fragments, thickness varies as well, but by no more than four centimeters.

\subsection{Variability of blanks}

We chose mass as principal criterion to measure the variability of blanks, given that in comparison with other metric measurements, the mass of tools seemed to be more suitable to demonstrate differences in tool dimensions and the functionality model. Three tendencies could be observed according to the distribution of tools by different tool types (Fig. 13). The first consists in the diversity of mass, ranging from $100 \mathrm{~g}$ to more than $2000 \mathrm{~g}$. The second lies in several peaks at $400 \mathrm{~g}, 600 \mathrm{~g}$ and $1200 \mathrm{~g}$. The third attests to partial consistency between mass and some specific types of tools. Two groups were identified; the first composed of types 7 to 12 and tools with convergent cutting-edge, which was more frequent 
in the range of 200-400 g and near 1000-1200 g, and the second group composed of types 1 to 6 , which is more regular between 400-600 $\mathrm{g}$ and $1200 \mathrm{~g}$.

In general, the tool blanks are extremely variable, which does not reflect the availability of blocks in the cave but rather the diversity of blocks in the external environment. It would appear that mass or at least volume was an important composition for the functionality of tools. The notion of type does not strictly correspond to a specific tool, but manifests a total range of different tools. Similarly, the mass range does not strictly correspond to specific tools, but exhibits a broad difference between tool types since we would not manipulate a tool of $400 \mathrm{~g}$ as we do for a tool of more than $1000 \mathrm{~g}$.

\subsection{Operative schemes of retouch}

For this part we are limited to indicating the principal differences which seem to be technologically pertinent. As shown above, apart from convergent tools, the lithic artifacts could be divided into two groups: one has a simple bevel (Fig. 14: a and b) ; the other has two opposite bevels in the form of a mirror (Fig. 14: $\mathrm{d}$ and e).

For tools with two opposite bevels in the form of a mirror (Types 2, 3 and 4) the beveled cutting-edges could be created after a series of retouch removals which had identical and/or different technical consequences. Thus two tools would be present on a single blank with the same volume. The retouch may form the transformative part with a plan-convex or plan-concave section depending on the type of retouch.

The contour of the cutting-edge varies (Fig. 15). In more than 125 retouched cutting-edges we observed in descending order: 62\% denticulate (Figs. 16 and 17), 14\% saw-like (Fig. 17: f), 10\% rostrum (Figs. 18 and 19), 8\% convergent with a denticulated edge and $6 \%$ beaked.

In each group of cutting-edges, some variability exists that clearly reflects different technical intentions corresponding to different effects on the materials to be processed. In addition, there seems to be a correlation between the depth and general contour of the cutting-edge for denticulates which are the most abundant of all types of cutting-edges. Of the denticulate cutting-edges $(\mathrm{N}=80), 47 \%$ are macro-denticulate rectilinear, $29 \%$ 
micro-denticulate rectilinear, $17 \%$ micro-denticulate convex symmetric and $3 \%$ asymmetric, and only $4 \%$ micro-denticulate concave. The correlation of these different types of denticulate cutting-edges with types of blanks indicates that the blanks of type 2, 6, 7, and 8 were specifically used to produce micro-denticulate convex or concave cutting-edges while the blanks of types 2 to 10 were selected to produce macro-denticulate cutting-edges except for types 4 and 9 which were never used to produce denticulate cutting-edges.

The second group of cutting-edges made on all types of blanks is that of rostrum. These cutting-edges may vary slightly in depth, with rectilinear straight, rectilinear macro-denticulate, convex straight, convex micro-denticulate contours. The blanks were composed of types 2, 6 and others (in this group we included all volume types with irregular morphology, and where variation in mass was less important than in other types of blanks) (Fig. 20). The saw-like tools were also made on specific blanks, types 4 and 9 (Fig. 20), which were the only blanks with parallel morphology on the bevel and increasing the length of the cutting-edge. The convergent tools were also distinguished from the others by their blanks of irregular flat morphology (Fig. 20). We therefore did not subdivide them into different types. It appears that this kind of tool required extremely thin blanks which were easy to shape, producing a triangular outline on one end and a desired form on the other.

\section{Discussion and conclusion}

The technical analysis indicates that the chaîne opératoire consists of three phases.

The first phase, far from the most negligible, consisted in selecting a blank with a large part presenting natural technical traits of the future tools. The operative schemes of this phase, which was based on selection, were carried out at the periphery of the cave and also inside the cave for some of the smaller blocks.

The second phase consisted in preparing the selected blank to obtain a definitive contour. By employing the operative schemes of shaping, the technical elements originally absent on the blank were created. The bevel would be the objective of the first step of shaping if it was not prepared in the first phase of selection. Most frequently it was created by a single removal. The two surfaces on the frontal face were not intentionally altered, and only the edges adjacent and opposite to the bevel were shaped. Similarly, the importance of this phase 
depended on whether the technical traits had been prepared in the selection phase. In general, the abrupt edges opposite the bevel were either natural or formed by a single removal while the abrupt edges adjacent to the bevel would be created by several removals always knapped from the same surface, associated or not with the remaining natural surface. Intersected removals for producing such abrupt edges were observed in only one case.

As an exception, for convergent tools and smaller tools, the blanks could be easily divided into different types. An operative scheme of reduction was attested by the presence of a single core. However, it could not be excluded that reduction took place outside the cave. Some large blanks show evidence of the flaking surface. It is very likely that reduction had occurred on an extremely large block to produce a pre-blank which would be subsequently treated by using the operative scheme of shaping. We observed apparent variability in blocks within the same type of blank. Some blanks for shaping weigh more than $2 \mathrm{~kg}$, with cutting-edges extremely similar to tools.

The third phase consisted in tool production. The objective was to create one or several cutting-edges. In general, the technique was internal hard hammer percussion. Some edges evidence peripheral percussion. The operative schemes seem to be well organized and a certain degree of consistency between the types of blanks and tools is manifest. Three groups were identified, in which several subdivisions could be further made. Similarly, a broad diversity was observed, attesting to different tools corresponding to different gestures and uses, since we would not manipulate a denticulate tool of more than $2 \mathrm{~kg}$ as we would for one of $200 \mathrm{~g}$. Nevertheless, it is not so much the fact of having massive tools in the assemblage but rather the strong disparity in mass which requires interpretation, as yet without elements of response.

Our analysis contributes to describing the technical patterns and the intended tools of the knappers. The analysis, layer by layer, shows the same patterns, yet it is not quantitatively significant. On the basis of currently available data, we could distinguish several layers of occupation which were dominated by the same broad technical options. These options were particularly distinct and surprising at first, but the repetition of operative schemes and functional intention could not have resulted from natural factors. In addition, from the beginning of this analysis, the depositional dynamics and post-depositional disturbance could 
by no means explain the alteration of these materials. There are no other comparable industries in stratigraphic context. What do we know about these regions? However, a behavior which long developed in East Asia can be observed. This concerns the importance of selection which consists in choosing a raw blank with technical traits closest to the future volume of tools already present. In other words, reduction was not the principal method to obtain the intended volumes. Shaping is largely predominant, but also played a partial role because it was used only to complete the acquired volume with additional traits needed before the final tool production stage. This kind of behavior has been identified in a large number of industries in all periods south of the Yangtze River, at the sites of Longgupo (Boëda et al.. 2011), Bose Basin (Hou et al., 2000; Wang et al., 2008, 2014; Bodin, 2011), Lixian of Hunan province (Bodin, 2011), Maomaodong (Cao, 1982a, 1982b), Chuandong (Zhang, 1995; Mao and Cao, 2009, 2012), Guanyindong of Guizhou Province (Li, 2011; Li et al., 2009, 2011; Li and Bodin, 2013).

The morpho-technological aspect of the Yumidong lithic industry exhibits a strong coherence and occupies an important place in the wide network of the technological dataset inside and outside South China toward the surrounding southern territories. In the course of the discoveries, Central-South China is shown to be a unique technical world in China and the lithic artifacts of Yumidong Cave are material clues of a potential local technological center of origin.

At present, Central-Southwest China occupies a determining strategic position to understand human peopling and faunal migration because it belongs to the northern realm of a wide subtropical paleobiogeographic area that includes the Ailuropoda-Stegodon complex covering the entire forested Southeast Asia. The Three Gorges themselves are located in the transitional zone between the upper and middle reaches of the Yangtze River (Changjiang River) where a large number of Paleolithic sites have been discovered in caves and along the fluvial terraces of the Yangtze River (Pei et al., 2013). Southward of this area is an overlapping environmental and technological unit including Vietnam, Laos, Thailand and Cambodia (Zeitoun et al., 2008) until Sumatra (Forestier et al.,2005, 2006, 2010; Forestier, 2007; Simanjuntak and Forestier, 2008). 
From the Pleistocene to the Holocene, the Southern Chinese Mountains were an anthropological, genetic, cultural and linguistic center of origin which is recognized as a homeland for the southern territories. Chinese prehistory and in particular that of the southern provinces underwent an original and atypical evolution of lithic technology similar to that of the nearby Southeast Asia which is characterized by the Hoabinhian phenomenon for $30 \mathrm{ka}$ (Forestier, 2000; Shoocongdej, 2006; Forestier et al., 2013).

The data of Yumidong have nothing in common with Old-World prehistory including Europe, Africa, the Near East and even the Indian Subcontinent and northern China where the industrial facies differ clearly between the Lower, Middle and Upper Palaeolithic. The Yumidong assemblage is more similar to the regions of mainland Southeast Asia (Thailand, Vietnam, Cambodia, Laos) and even the archipelago (Philippines, Indonesia) where lithic techno-complex chronologically attributed to the "Upper Paleolithic period" for the most part shows persistence and continuity with the Lower Paleolithic methods with very heavy, angular and massive stone tools made on pebbles, cobbles and other blanks. Moreover, the Levallois and blade/bladelet phenomenon is unknown in the prehistory of Central-South China and Southeast Asia while it is well known in Western Europe, but also in Arabia (Armitage et al., 2011), Africa (Van Peer et al., 2003; Nicoll, 2009; Soriano et al., 2010) and even in Asia (Zwyns, N., 2012; Zwyns et al., 2014), until northern China (Bordes, 1968; Derevianko et al., 1995; Jaubert et al., 1997; Pei et al., 2012; Boëda et al., 2012).

The uniqueness of the subtropical lithic assemblage of Yumidong consists in a tool kit exclusively made of massive stone tools during the Middle and Late Pleistocene which would be understandable as the result of a successful adaptation of hominids to a specific environment. This area becomes increasingly forested, wet and tropical as one approaches the $17^{\text {th }}$ parallel North near the Vietnamese border. These artifacts are a technical/anthropological response to geographical and ecological determinism.

Very massive lithic assemblages knapped on blocks, plates, cobbles and pebbles are constant in the diachrony of Southeast Asia from the Early Upper Palaeolithic until recent times (Holocene) as the Hoabinhian technocomplex which has been dated to the end of the Upper Pleistocene (around $30 \mathrm{ka}$ to $5 \mathrm{ka}$ ). The Hoabinhian began to appear in Yunnan (Zeitoun et al., 2008) and probably moved through the Southeast Asia countries up to the 
island of Sumatra in Indonesia (Moser, 2001). This techno-complex, spread across several million $\mathrm{km}^{2}$, consisted of several chaînes opératoires mainly to produce choppers, chopping tools, unifacial tools and split tools on thin/flat pebbles and cobbles (Forestier, 2000; Marwick 2008; Forestier et al., 2013). Like other technical facies, the Hoabinhian techno-complex used a shaping method on blocks, cobbles and pebbles to produce heavy stone tools which were a response to the tropical forest environment (Solheim, 1972).

The massive lithic assemblage of Yumidong is not an isolated case but an original, effective, and specific response to the environment which (certainly) foreshadows other new but as yet unknown adaptations connected with the emergence of modern humans in China. This is another case of a "survival stone tool kit" made by humans. As such, the lithic industries of Central-South China continue to address the question of variability in modern human technical behavior and deconstruct the evolutionist paradigms made by Western researchers based on the gradual Modes 1, 2, 3, etc., which have no place in Eastern and Southeast Asian prehistory.

\section{Acknowledgements}

The excavation was supported by the Archaeological Excavation Project of State Adminstration of Cultural Heritage (the Archaeological Excavation of the Yumidong Cave site, No. 2013-73), the Chongqing Social Science Planning Project (the Preliminary Study of the Yumidong Cave site, 2014), the Program of SRF for ROCS, SEM. The present research work was supported by the CAS Strategic Priority Research Program Grant (No. XDA05130203), the National Science Foundatoin of China (No. 41272033). The French participation was supported by l'ANR (National Agency of Research, France)-CNRS-Espace et territoire: Les énigmes spatiales de la vie en sociétés, Editions 2010 (Axe thématique 7: L'innovation spatiale, thème: L'altérité technico-culturelle du continent asiatique: vers une nouvelle histoire de l'homme? Coordinateur Pr. Boëda Eric). U/Th dating was supported by J.X. Zhao's Australian Research Council Research Grants (DP0773081 and LE0989067).

\section{References}


Aigner, J.S., 1981. Archaeology Remains in Pleistocene China. C. H. Beck, Munich.

Armitage, S., Jasim, S., Marks, A., Parker, A., Usik, V., Uerpmann, H.-P., 2011. The Southern Route "Out of Africa": Evidence for an Early Expansion of Modern Humans into Arabia. Science 331, 453-56.

Bodin, E., 2011. Analyses techno-fonctionnelle des industries à pièces bifaciales aux Pléistocene inférieur et moyen en Chine. Unpublished Ph.D dissertation. University of Paris Ouest Nanterre la Défense, Paris.

Boëda, E., Hou, Y.M., 2011. Analyse des artéfacts lithiques du site de Longgupo. L'Anthropologie 115, 78-175.

Boëda, E., Hou, Y.M., Forestier, H., Sarel, J., Wang, H.M., 2012. Levallois and non-Levallois blade production at Shuidonggou in Ningxia, North China. Quaternary International 295, 191-203.

Bordes, F., 1968. Le Paléolithique dans le monde. L'Univers des connaissances, Paris, Hachette, Coll. 256 p.

Cao, Z.T., 1982a. The preliminary study of bone tools and antler spades from the rock shelter site of Maomaodong. Acta Anthropologica Sinica 1, 36-41.

Cao, Z.T., 1982b. On the Paleolithic artifacts from Maomaodong (the rock-shelter site), Guizhou Province. Vertebrata PalAsiatica 20, 155-164.

Chia, L.P., 1957. Notes on the human and some other mammalian remains from Changyang, Hubei. Vertebrata PalAsiatica 1, 247-257.

Clark, T.R., Zhao, J.X., Feng, Y.X., Done, T.J., Jupiter, S., Lough, J., Pandolfi, J.M., 2012. Spatial variability of initial $230 \mathrm{Th} / 232 \mathrm{Th}$ in modern Porites from the inshore region of the Great Barrier Reef. Geochimica et Cosmochimica Acta 78, 99-118.

Derevianko, A., Petrin, V., 1995. The Levallois of Mongolia. In: Dibble, H., Bar-Yosef, O. (dir.), The definition and interpretation of Levallois technology, Monographs in World Archaeology 23. The University Museum of Archaeology and Anthropology, University of Pennsylvania, Philadelphia, pp.456 -473.

Dong, M.X., 1998. A preliminary report on Paleolithic remains in Sunjiadong Paleolithic site in Hubei province. Acta Anthropologica Sinica 18, 144-146. 
Forestier,H., 2000. De quelques chaînes opératoires lithiques en Asie du Sud-Est au Pléistocène supérieur final et au début de l'Holocène. L'Anthropologie 104, 531-548.

Forestier, H., 2007. Les éclats du passé préhistorique de Sumatra: une longue histoire des techniques. Archipel 74, 15-44.

Forestier, H., Simanjuntak, H.T., Guillaud, D., Driwantoro, D., Wiradnyana, K., Siregar, D., Due, Awe, R., Budiman, 2005. Le site de Tögi Ndrawa, île de Nias, Sumatra nord: les premières traces d'une occupation hoabinhienne en grotte en Indonésie. Comptes rendues Palevol 4, 727-733.

Forestier, H., Driwantoro, D., Guillaud, D., Budiman, 2006. New data about Prehistoric chronology of South Sumatra. In: Simanjuntak, T. et al. (Eds.), Archaeology: Indonesian Perspective. R.P. Soejono Festschriift. LIPI, Jakarta, pp. 177-192.

Forestier, H., Simanjuntak, H.T., Detroit, F., Zeitoun, V., 2010. Unité et diversité préhistorique entre Java et Sumatra. Archipel 80, 19-44.

Forestier, H., Zeitoun, V., Winayalai, C., Metais, C., 2013. The open-air site of Huai Hin (Northwestern Thailand): Chronological perspectives for the Hoabinhian. Comptes rendues Palevol 12, 45-55.

Gao, X., Huang, W.B., Xu, Z.Q., Ma, Z.B., Olsen, J.W., 2004. 120-150 ka human tooth and ivory engravings from Xinglongdong Cave, Three Gorges region, South China. Chinese Science Bulletin 49, 175-180.

Han, D.F., Xu, C.H., 1989. Quaternary mammalian faunas and environment of fossil humans in South China. In: Wu, R.K., Wu, X.Z., Zhang, S.S. (Eds.), Early Humankind in China. Science Press, Beijing, pp. 338-391.

Hou, Y.M., Potts, R., Yuan, B.Y., Guo, Z.T., Deino, A., Wang, W., Clark, J., Xie, G.M., Huang, W.W., 2000. Mid-Pleistocene acheulean-like stone technology of the Bose Basin, south China. Science 287, 1622-1626.

Huang, W.B., Xu, Z.Q., 2002. The Fengjie Man of 140, 000 Years Old: An Ancient Human Site Found at Tiankeng-Difeng Region. Chung Huwa Book Company, Beijing.

Huang, W.B., Xu, Z.Q., Zheng, S.H., 2000. A preliminary report on the test excavation of Migong Cave Paleolithic site, Wushan. Longgupo Prehistoric Culture 2, 7-63. 
Jaubert, J., Giscard, P.-H., Batsaikhan, Z., Erdenebaatar, D., Servelle, C., 1997. Contribution à la connaissance du Paléolithique de Mongolie: étude des sites de l'Aimak de Hovd (Altai Mongol). L’Anthropologie 101, 419-447.

Li, Y.H., 2011. Etude technologique de l'industrie lithique du site de Guanyindong dans la province du Guizhou, sud-ouest de la Chine. @ rchéo-editions.com, France.

Li, Y.H., Bodin, E., 2013. Variabilité et homogénéité des modes de débitage en Chine entre 300000 et 50000 ans. L'Anthropologie 117, 459-493.

Li, Y.H., Bodin, E., Hou, Y.M., 2011. New perspective of studying lithic industry: techno-functional method-A case of the Guanyindong site. Archaeology 9, 58-70.

Li, Y.H., Hou, Y.M., Boëda, E., 2009. Mode of débitage and technical cognition of hominids at the Guanyindong site. Chinese Science Bulletin 54, 3864-3871.

Ludwig, K.R., 2003. Users Manual for Isoplot/EX 3.0: A Geochronological Toolkit for Microsoft Excel. Berkeley Geochronology Center: Special Publication No. 4.

Mao, Y.Q., Cao, Z.T., 2009. Excavated lithic artifacts in Chuandong prehistoric site in Puding County, Guizhou Province. Guizhou Science 27, 38-42.

Mao, Y.Q., Cao, Z.T., 2012. A preliminary study of the polished bone tools unearthed in 1979 from the Chuandong site in Puding County, Guizhou. Acta Anthropologica Sinica 31, $335-343$.

Marwick, B., 2008. Lithic artifacts and Human Ecology at Two Rockshelters in Northwest Thailand. Unpublished Ph.D., Archaeology and Natural History. The Australian National University, Canberra.

Moser, J., 2001. Hoabinhian, Geographie und Chronologie eines steinzeitlichen Technocomplexes in Südöstasien. Unden Soft.

Nicoll, K., 2009. Evidence of Levallois technique at a Middle Stone Age open-air site along the Angola-Namibia border. Antiquity 83, project gallery.

Pei, S., Gao, X., Wang, H., Kuman, K., Bae, C., Chen, F. Guan, Y., Zhang, Y., Zhang, X., Peng, F., Li, X., 2012. The Shuidonggou site complex: new excavations and implications for the earliest Late Paleolithic in North China. Journal of Archaeological Science 39, $3610-3626$. 
Pei, S., Gao, X, Wu, X., Li, X., Bae, C. 2013. Middle to Late Pleistocene hominin occupation in the Three Gorges region, South China. Quaternary International 295, 237-252.

Roff, G., Clark, T.R., Reymond, C.E., Zhao, J.X., Feng, Y.X., McCook, L.J., Done, T.J., Pandolfi, J.M., 2013. Palaeoecological evidence of a historical collapse of corals at Pelorus Island, inshore Great Barrier Reef, following European settlement. Proceedings of the Royal Society B-Biological Sciences 280(1750).

Shoocongdej, R., 2006. Late Pleistocene activities at the Tham Lot rockshelter inhighland Pang Mapha, Mae Hong Son province, northwestern Thailand. In: Bacus, E., Glover, I., Pigott, V. (Eds.), Uncovering Southeast Asia's Past, Singapore University Press, pp. 22-37.

Simanjuntak, H.T., Forestier, H., 2008. Handaxe in Indonesia. A question on the Movius Line. Human Evolution 23, 97-107.

Solheim, W., 1972. The "new look" of Southeast Asian prehistory. Journal of Siam Society $60,1-20$.

Soriano, S., Rasse, M., Tribolo, C., Huysecom, E., 2010. Ounjougou: a long Middle Stone Age sequence in the Dogon country (Mali).In: Allsworth-Jones, P. (dir.), West African Archaeology: New developments, new perspectives. British Archaeological Reports, pp. $1-14$.

Van Peer, P., Fullagar, R., Stokes, S., Bailey, R., Moeyersons, J., Steenhoudt, F., Geerts, A., Vanderbeken, T., De Dapper, M., Geus, F., 2003. The Early to Middle Stone Age Transition and the Emergence of Modern Human Behaviour at site 8-B-11, Sai Island, Sudan. Journal of Human Evolution 45, 187-93.

Wang, W., Bae, C.J., Huang, S.M., Huang, X., Tian, F., Mo, J.Y., Huang, Z.T., Huang, C.L., Xie, S.W., Li, D.W., 2014. Middle Pleistocene bifaces from Fengshudao (Bose Basin, Guangxi, China). Journal of Human Evolution 69, 110-122.

Wang, W., Mo, J.Y., Huang, Z.T., 2008. Recent discovery of handaxes associated with tektites in the Nanbanshan locality of the Damei site, Bose Basin, Guangxi, South China. Chinese Science Bulletin 53, 878-883.

Zeitoun, V., Forestier, H., Nakbunlung, S., 2008. Préhistoires au sud du Triangle d'Or. IRD Editions, Paris. 
Zhang, S.S., 1995. A brief study on Chuandong prehistoric site (excavation in 1981). Acta Anthropologica Sinica 14, 132-146.

Zhao, J.X., Hu, K., Collerson, K.D., Xu, H.K., 2001. Thermal ionization mass spectrometry U-series dating of a hominid site near Nanjing, China. Geology 29, 27-30.

Zhou, H.Y., Zhao, J.X., Wang, Q., Feng, Y.X., Tang, J., 2011. Speleothem-derived Asian summer monsoon variations in Central China during 54-46 ka. Journal of Quaternary Sciences 26, 781-790.

Zwyns, N., 2012. Laminar Technology and the Onset of the Upper Paleolithic in the Altai, Siberia. In: Studies in Human Evolution. Leiden University Press, Leiden.

Zwyns, N., Gladyshev, S.A., Gunchinsuren, B., Bolorbat, T., Flas, D., Dogandzic, T., Tabarev, A.V., Gillam, J.C., Khatsenovich, A.M., McPherron, S., Odsuren, D., Paine, C.H., Purevjal, K.-E., Stewart, J.R., 2014. The open-air site of Tolbor 16 (Northern Mongolia) : Preliminary results and perspectives. Quaternary International 347, 53-65.

Fig. 1. Location of the Yumidong Cave site.

Fig. 2. Plan view of the Yumidong site and excavation units showing the location of the skylight.

Fig. 3. Stratigraphic sequence (left) and dating samples (right) of Yumidong Cave (T4). The samples of 12YMDT4-3-54-calcite and 12YMDT4-3-54-tooth have been cemented together tightly, therefore they shared the same number of 12YMDT4-3-54.

Fig.4. Representative mammalian fossils unearthed from the Yumidong Cave. A, left $\mathrm{m} 3$ of Ursus thibetanus, crown view; B, left m1 of Ailuropoda melanoleuca baconi, crown view; C, left $\mathrm{m} 1$ of Crocuta crocuta, lingual view; D, mandible of Canis sp., labial view; E, right p2 of Equus sp., crown view; F, left P3/4 of Megatapirus augustus, crown view; G, right DP4 of Stephanorhinus sp., crown view; H, left P4 of Stegodon orientalis, crown view; I, left antler of Cervus unicolor, internal view; J, left m1-m3 of Bubalus sp., crown view. Scale bar: $4 \mathrm{~cm}$. Fig. 5. Types of volumetric structures. Types 1 to 9 represent volumetric structure with bevel(s); Types 10 to 12 represent trihedral structure.

Fig. 6. Orientation and definition of the different faces constituting a tool.

Fig. 7. Volumetric structure of Type 1 made on plaquette. The opposite back on bevel was created by a negative of removal corresponding to a fracture by flexion. The two lateral sides 
were shaped to create two abrupt surfaces. The bevel was created by a single removal forming an angle of 50 degrees. It was subsequently retouched to accomplish the transformative part. The scale represents $5 \mathrm{~cm}$.

Fig. 8. Volumetric structure of Type 2 with cutting edge created by opposing retouch.

Fig. 9. Volumetric structure of Type 4 with saw-like cutting-edge.

Fig. 10. Convergent tools with macro-denticulate cutting-edge.

Fig. 11. Convergent tools with macro-denticulate cutting-edge. The scale represents $20 \mathrm{~cm}$.

Fig. 12. Convergent tools. a, b and c represent simple or multiple convergent tools. The cutting-edge is micro-denticulate or rectilinear; $\mathrm{d}$ was a beak made on a type 4 blank.

Fig. 13. Distribution of mass according to different types of blank.

Fig. 14. Location of the retouch.

Fig. 15. Different contours of cutting-edges.

Fig. 16. Denticulate cutting-edge on type 4 blank. The scale represents $5 \mathrm{~cm}$.

Fig. 17. a, rectilinear micro-denticulate cutting-edge on type 4 blank; b and e, macro-denticulate cutting-edge on blank of types 1 and 5; c and d, macro-denticulate cutting-edge with convex outline on blank of types 1 and 2 ;F, saw-like edge on type 5 blank.

Fig. 18. Rostrum on type 6 blank. The scale represents $20 \mathrm{~cm}$.

Fig. 19. a. rostrum with convex denticulate outline on blank of type 8 , b. rostrum with convex linear outline on type 1 blank.

Fig. 20. Distribution of different groups of cutting-edges by different types of blanks.

Table 1: U-Th analysis and dating results for the Yumidong Cave. (Sample name: 12: sample obtained in 2012; YMD: Yumidong cave site; T3 or T4: test pit; -2, 3 or 4: layer; -\#: unique ID.)

Table 2: Frequency of tools by volumetric structure. 

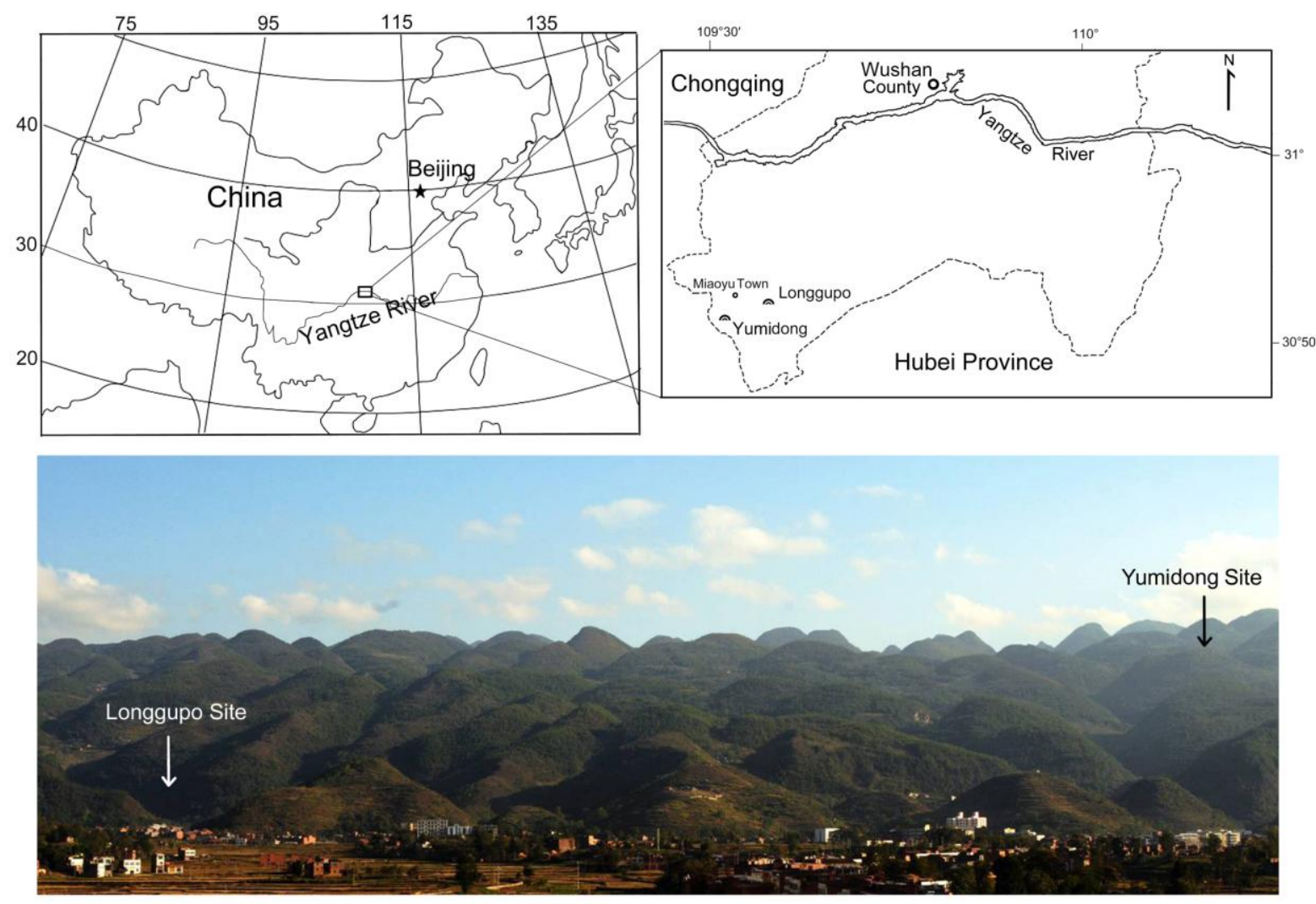


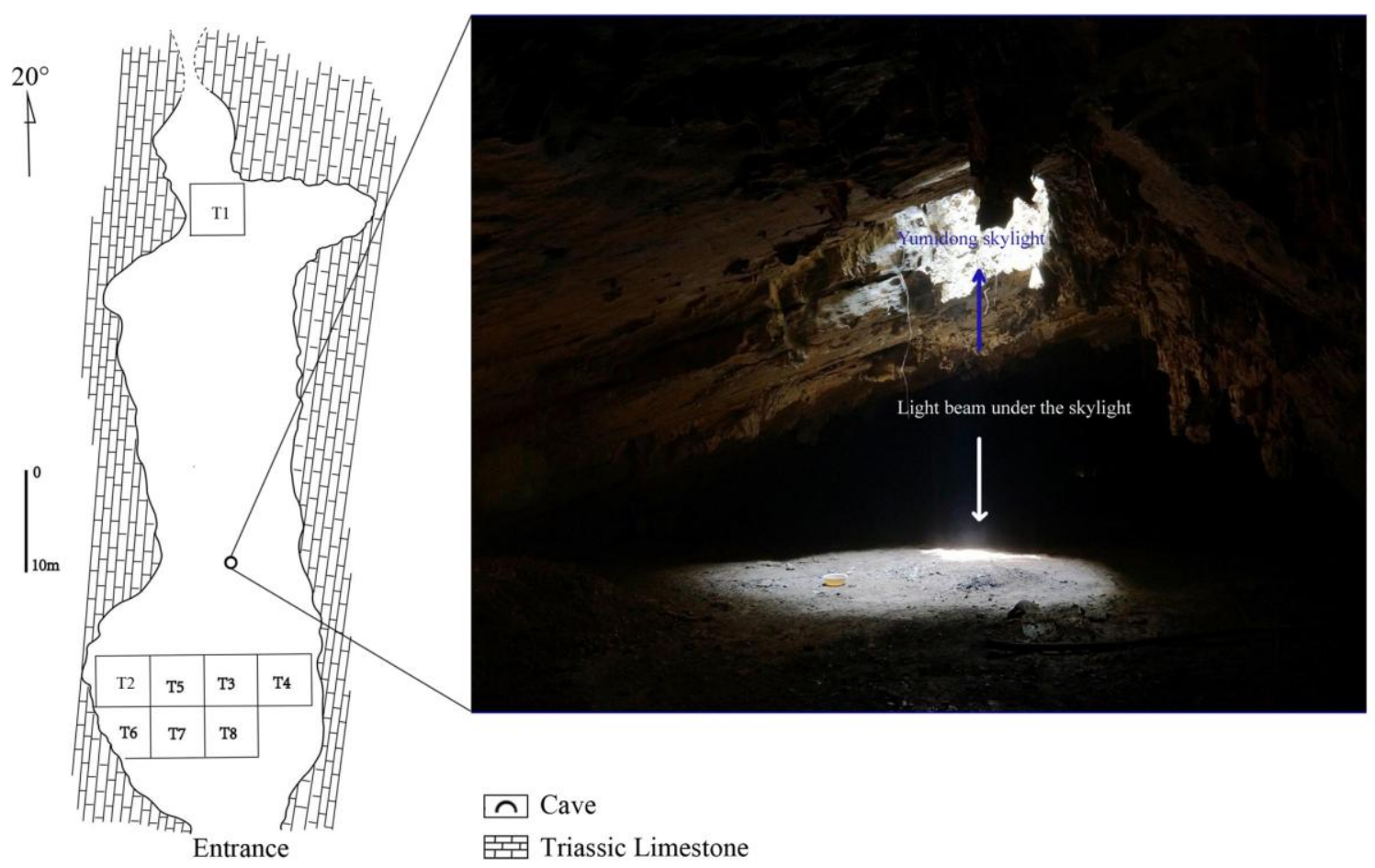




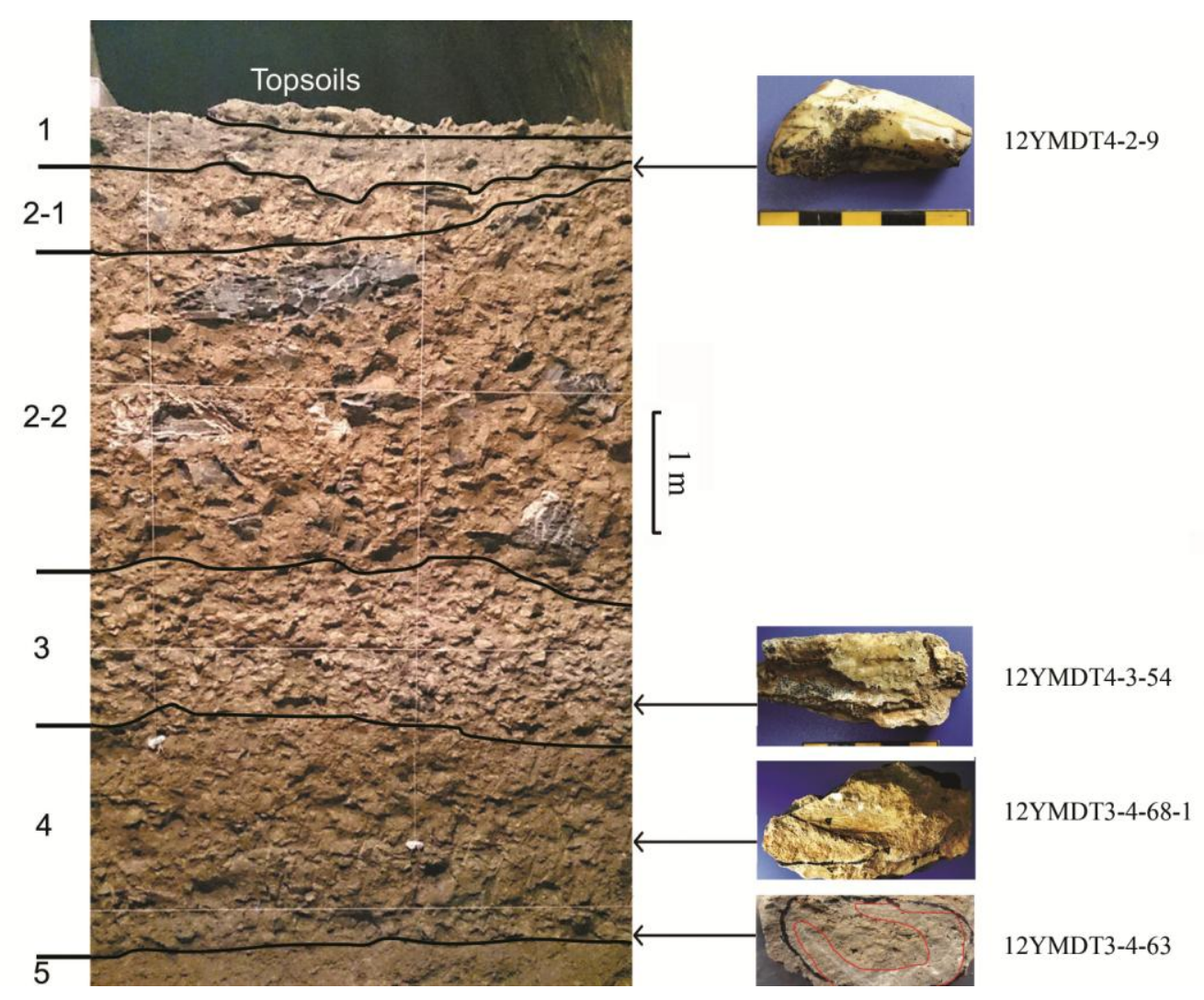




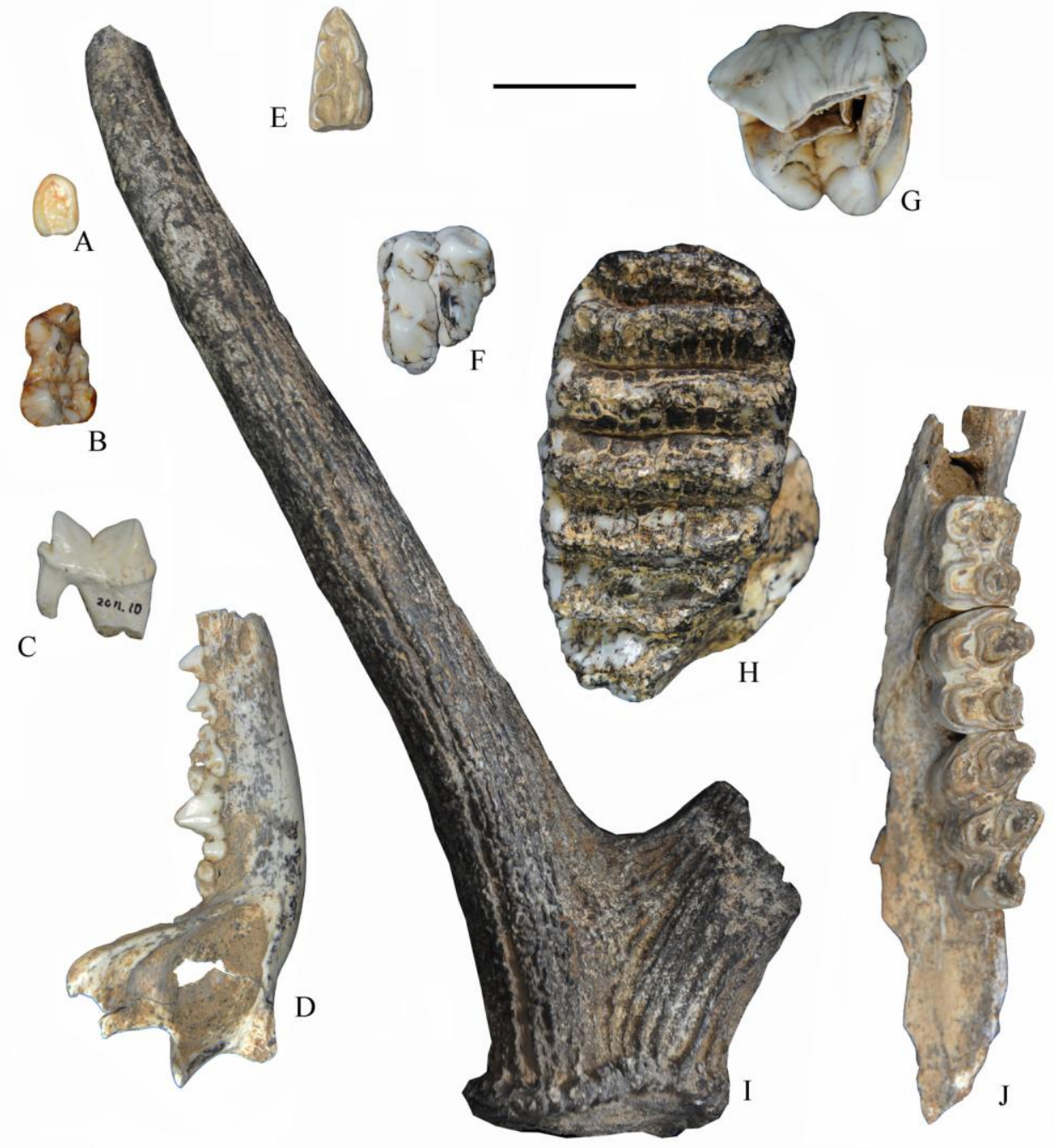




\begin{tabular}{|l|l|l|l|l|}
\hline Type 1 & Type 4 \\
\hline Type 5 & Type 6 & Type 3 \\
\hline
\end{tabular}




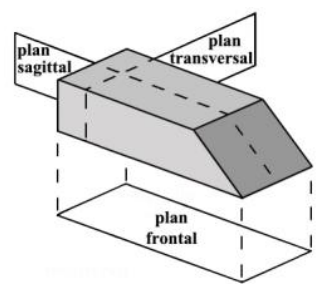




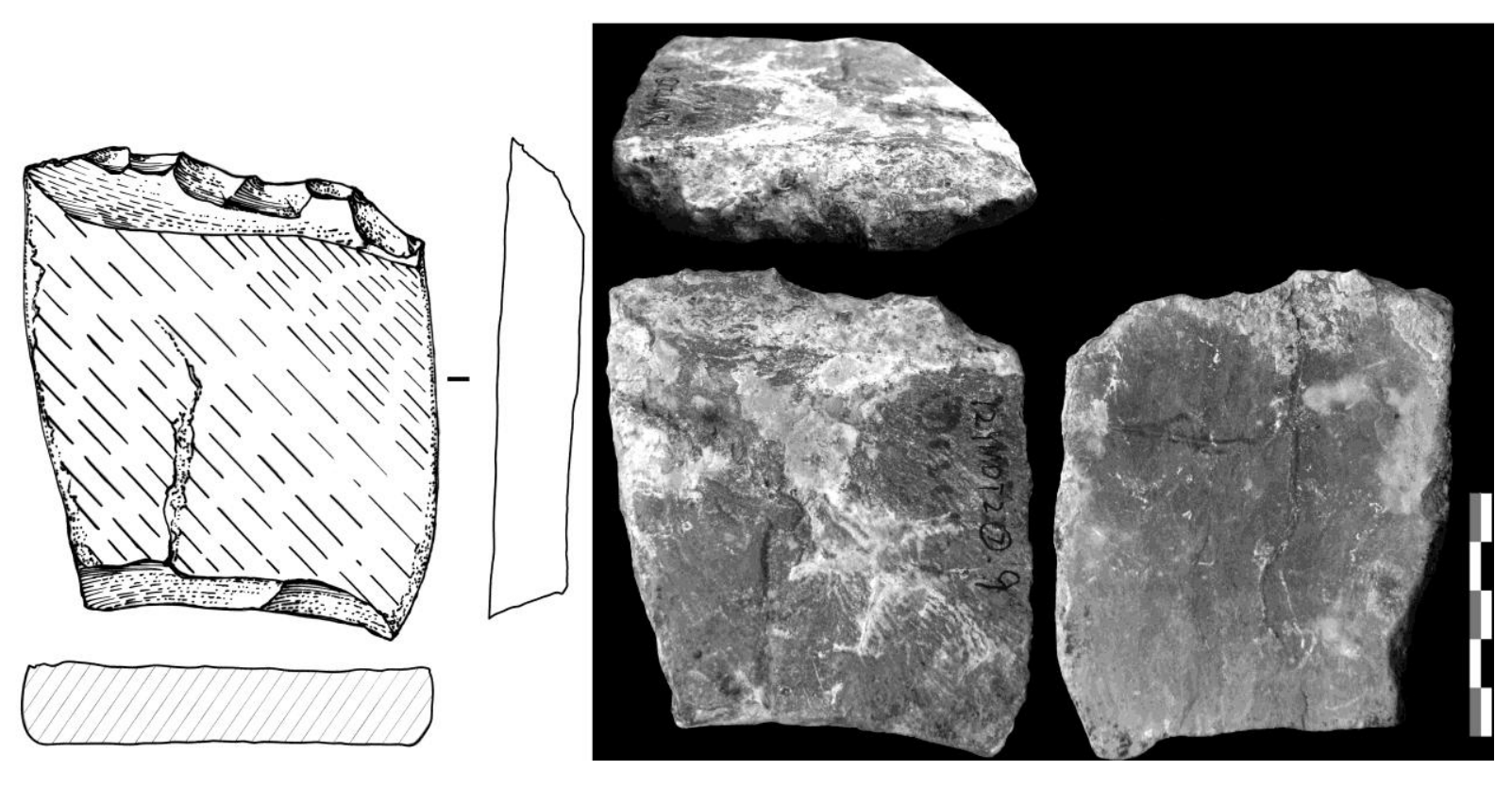




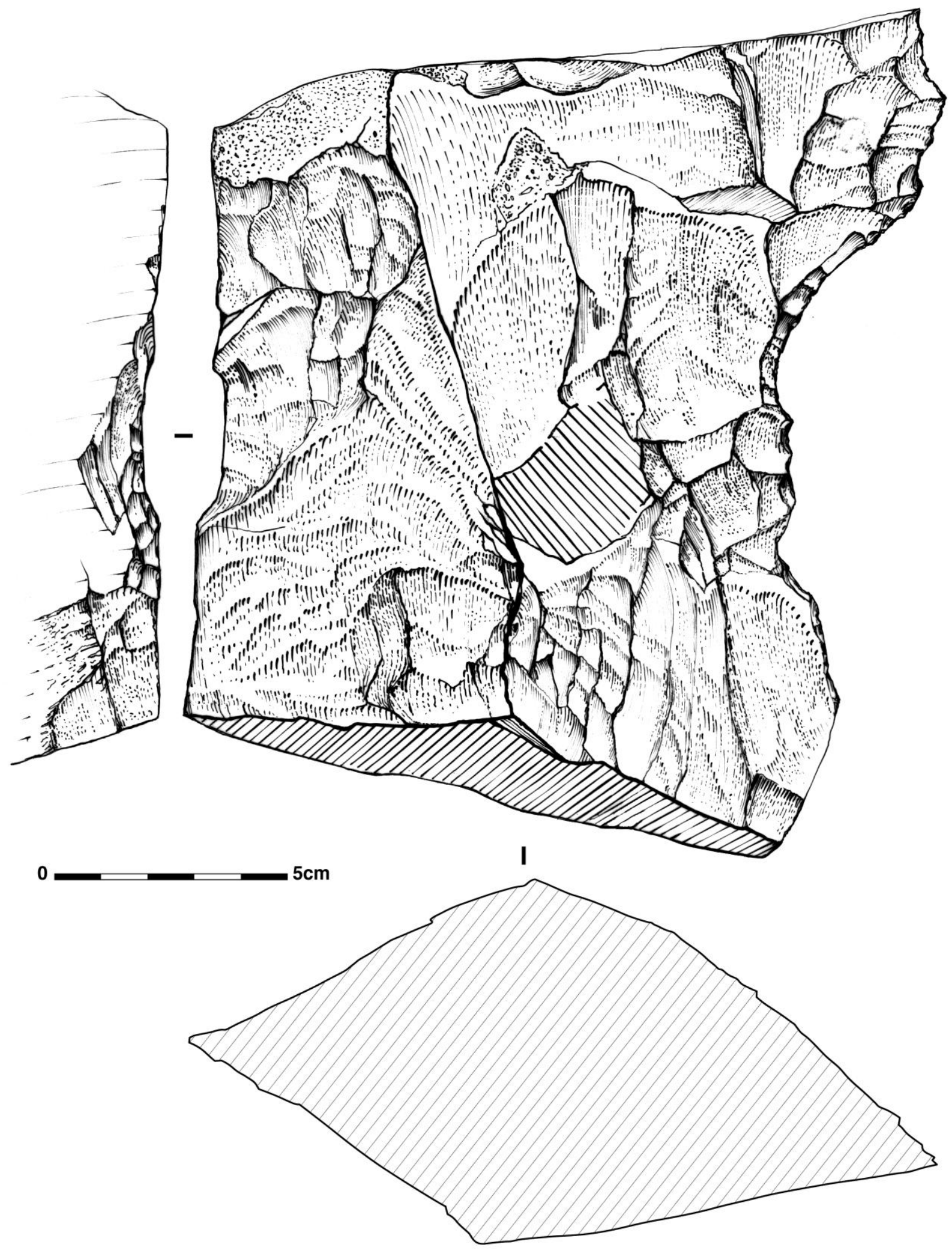



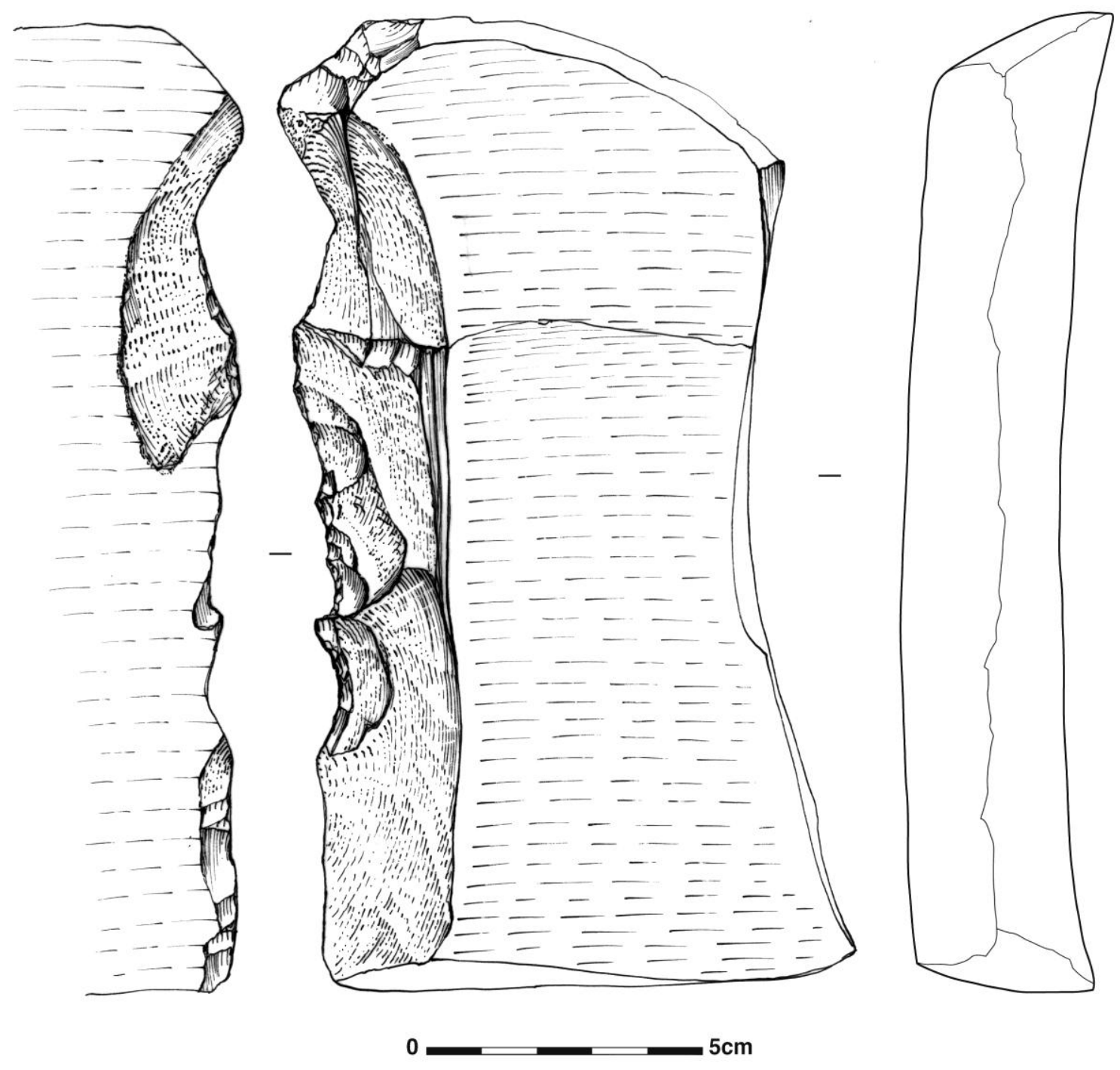


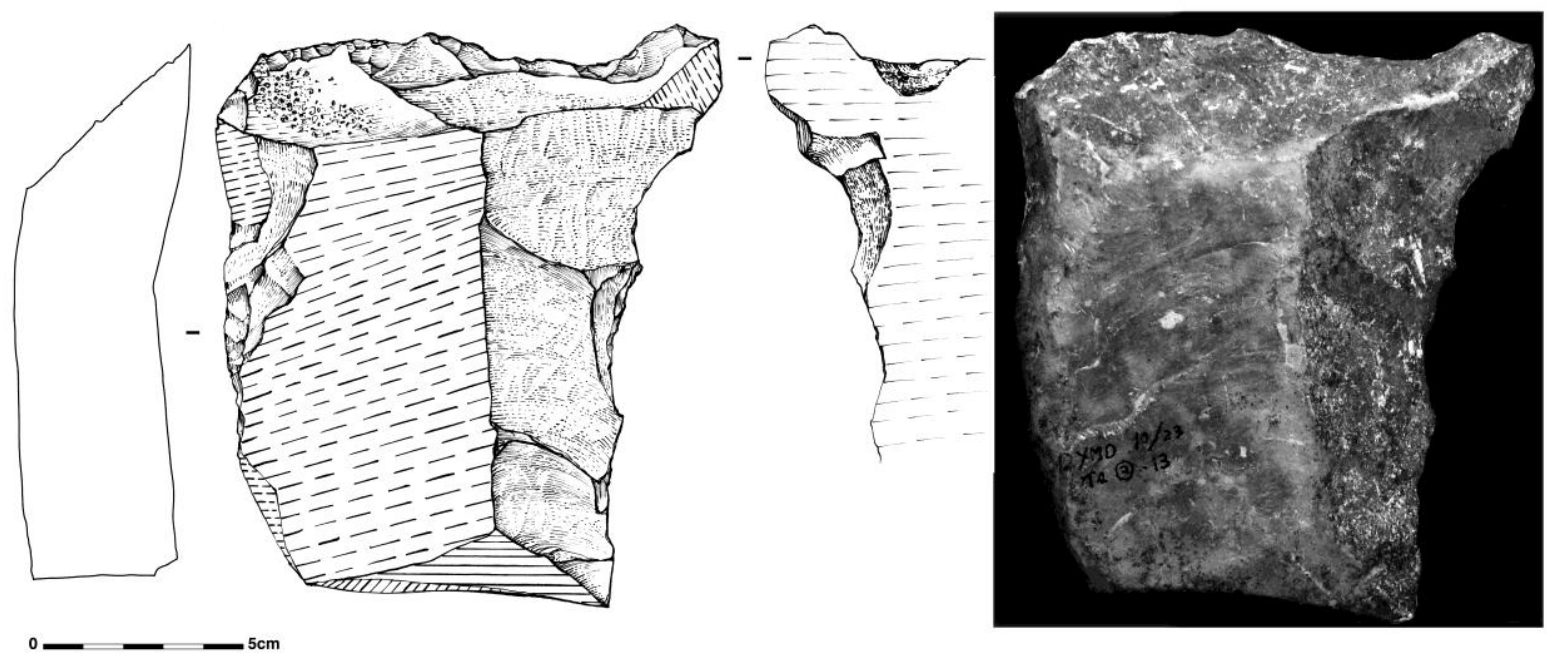




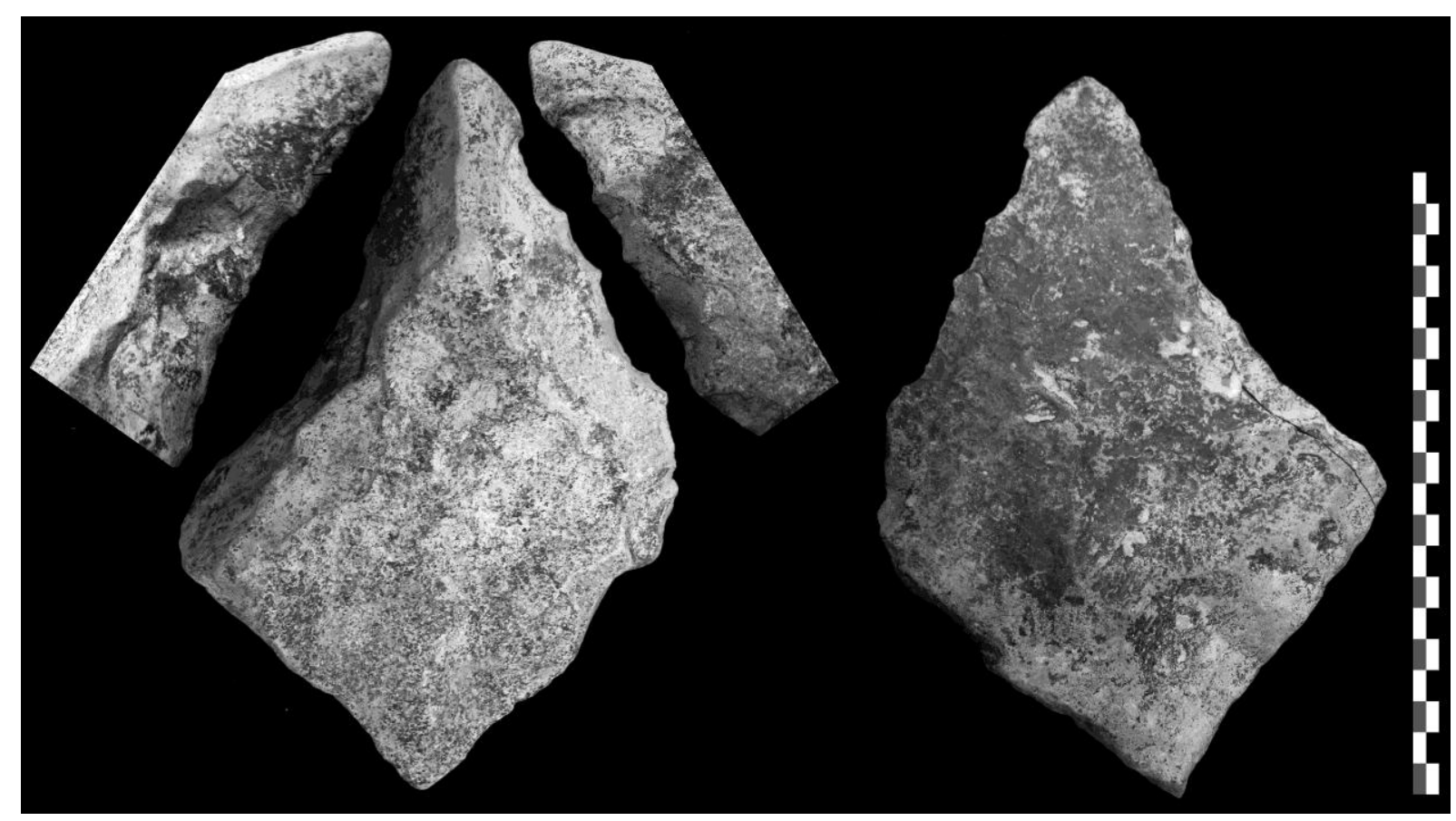



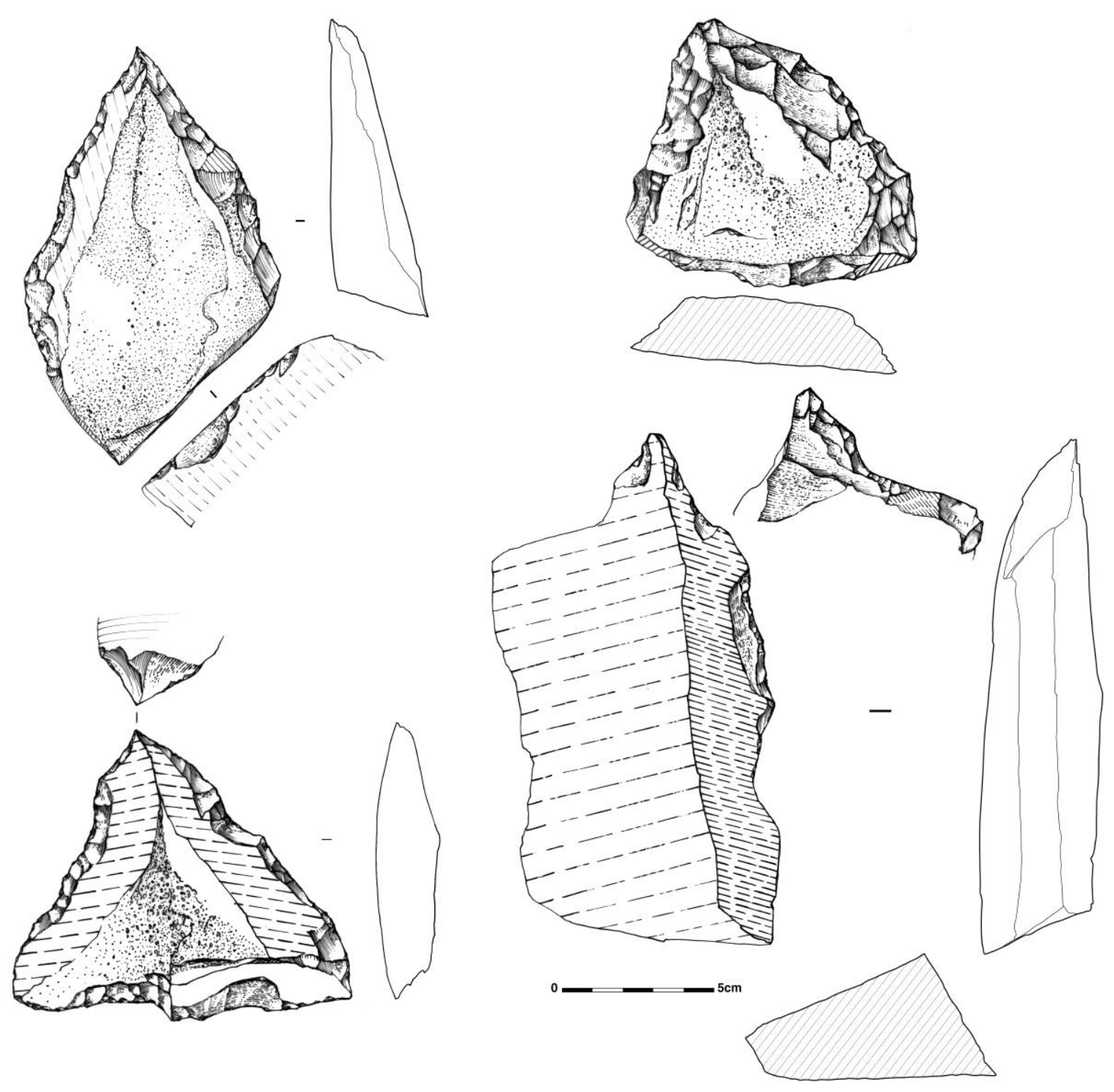


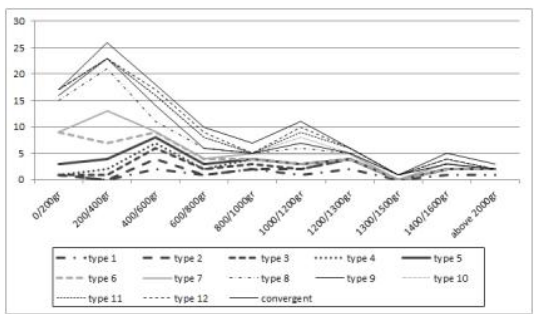


localization of the retouch

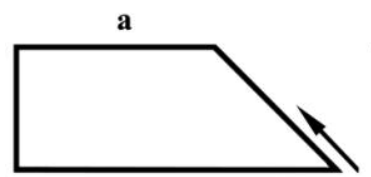

simple bevel one cutting edge

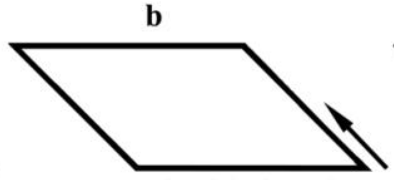

double bevel one cutting edge

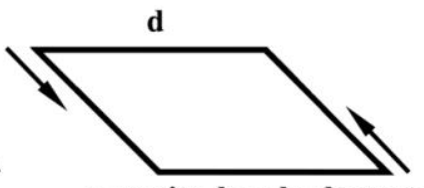

opposite bevels alternate two cutting edges

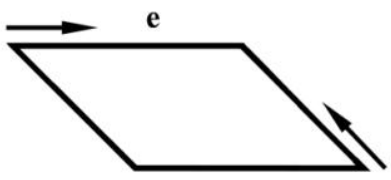

opposite bevels two cutting edges 


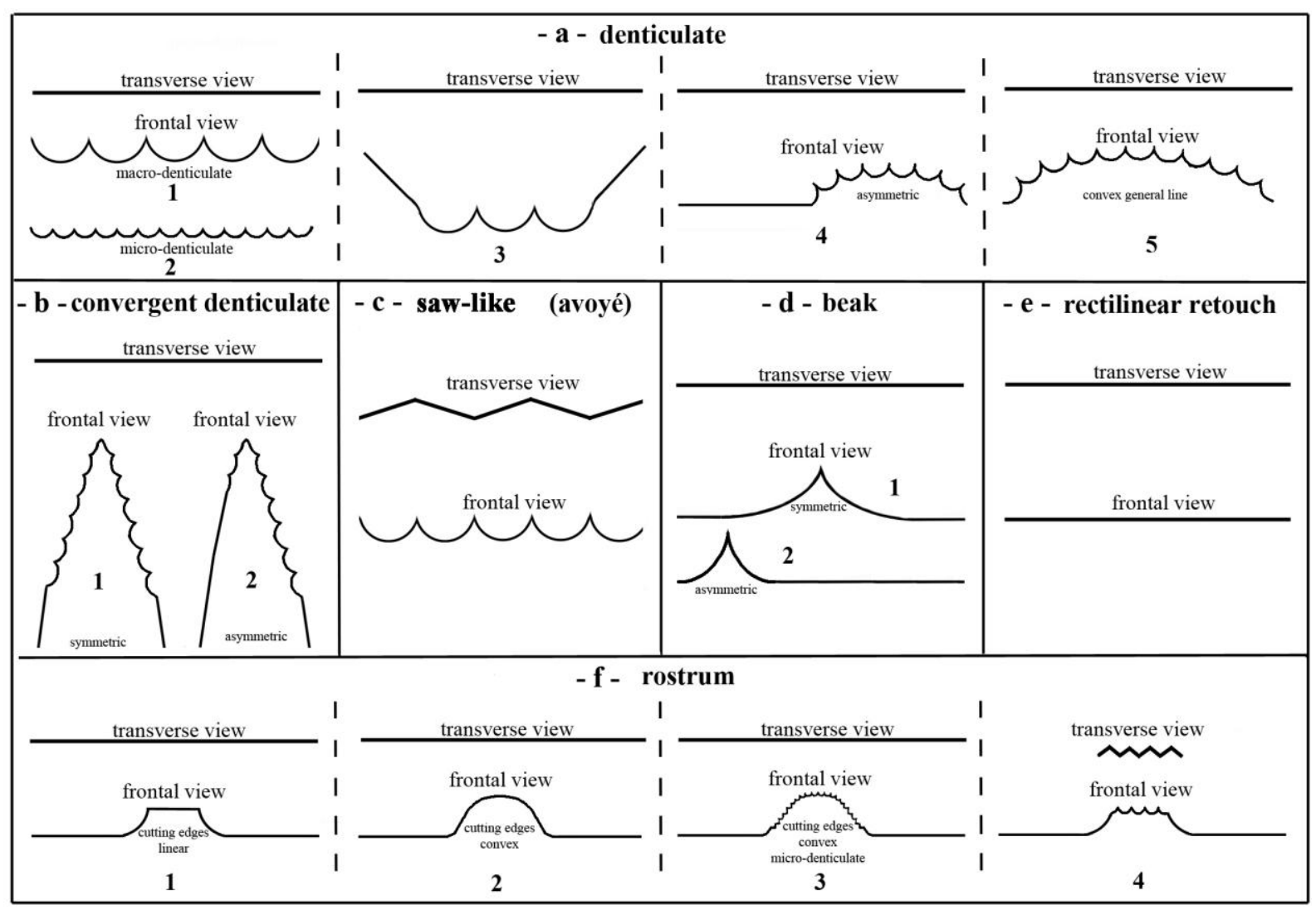




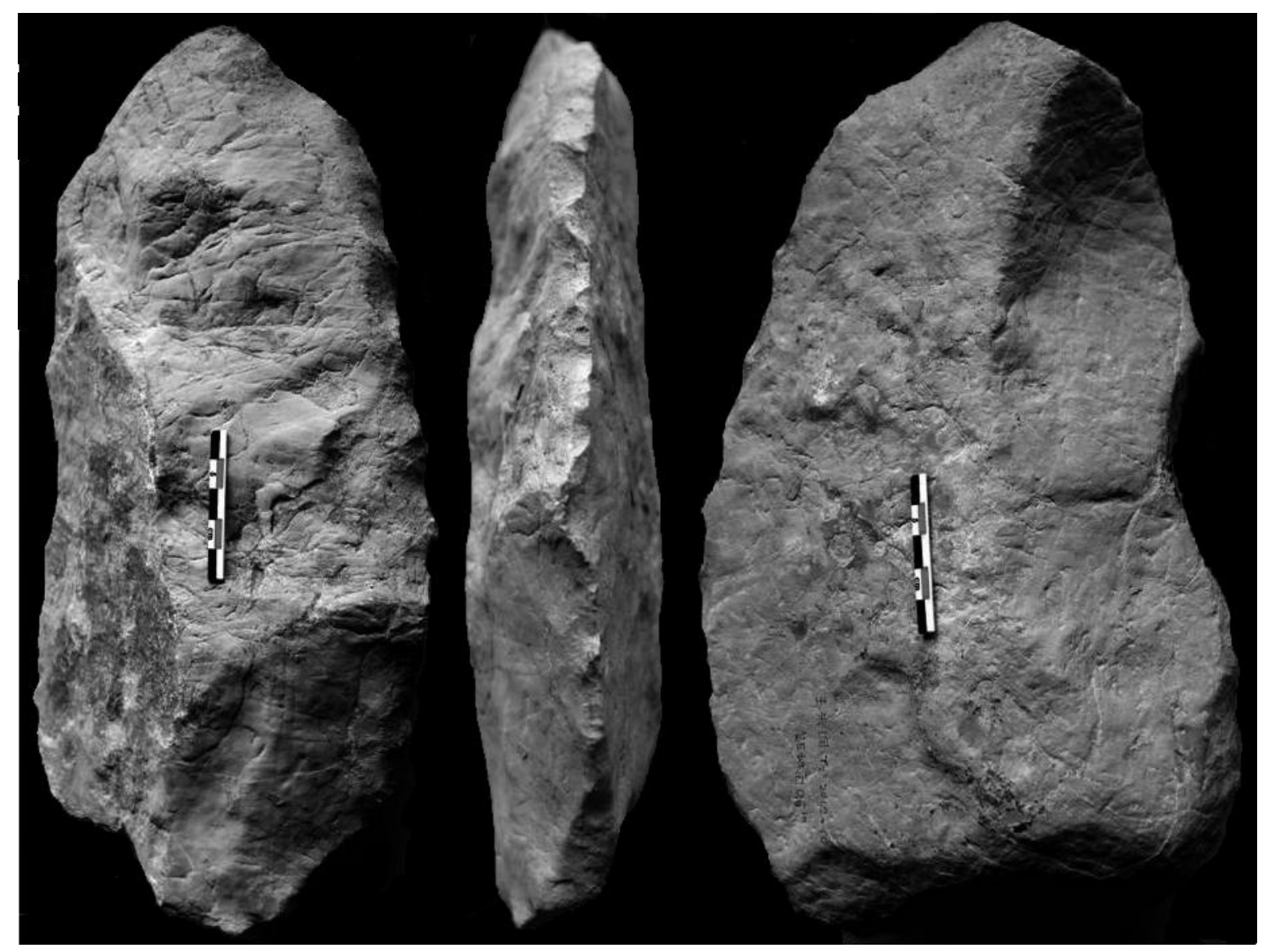



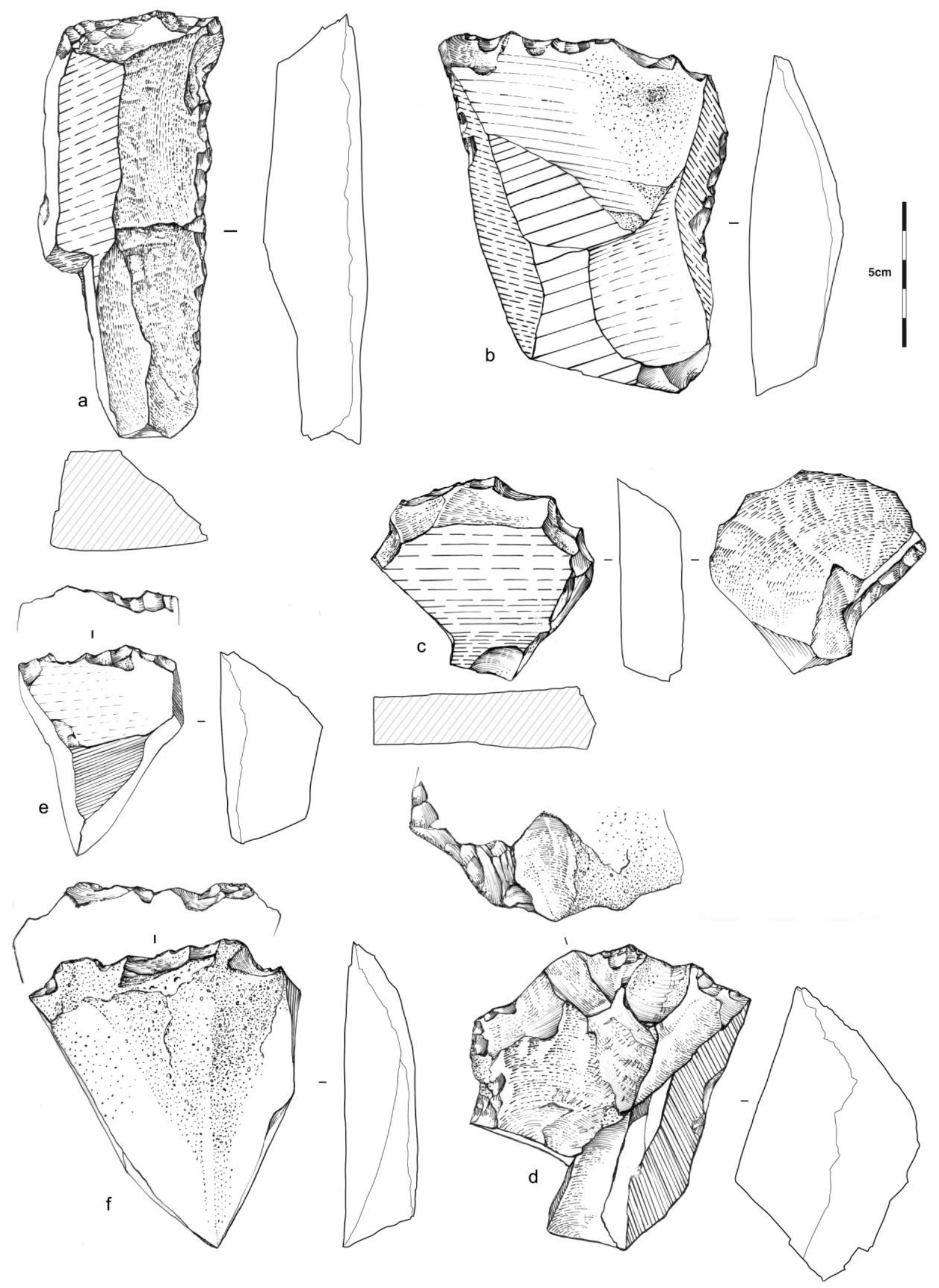


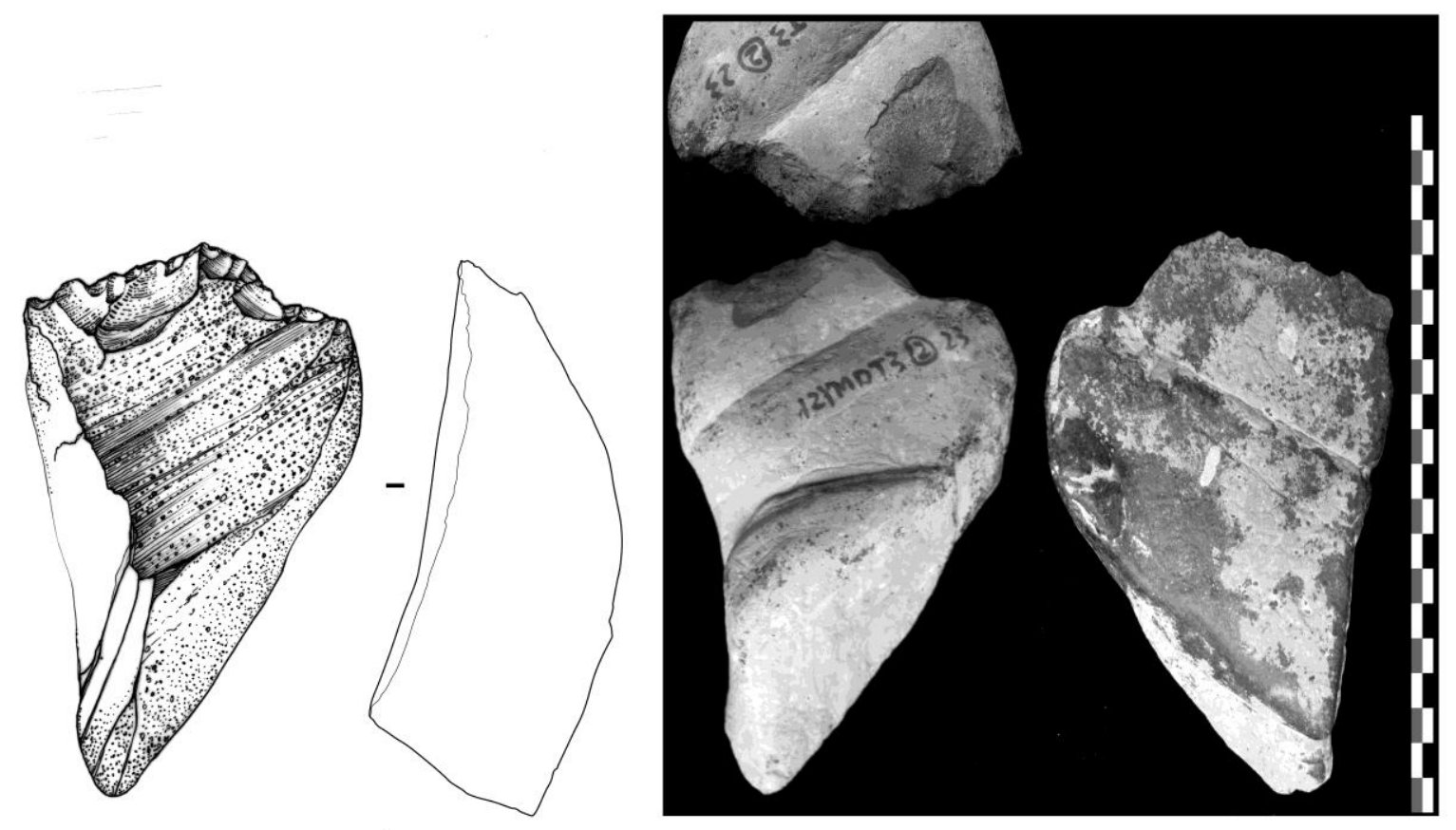



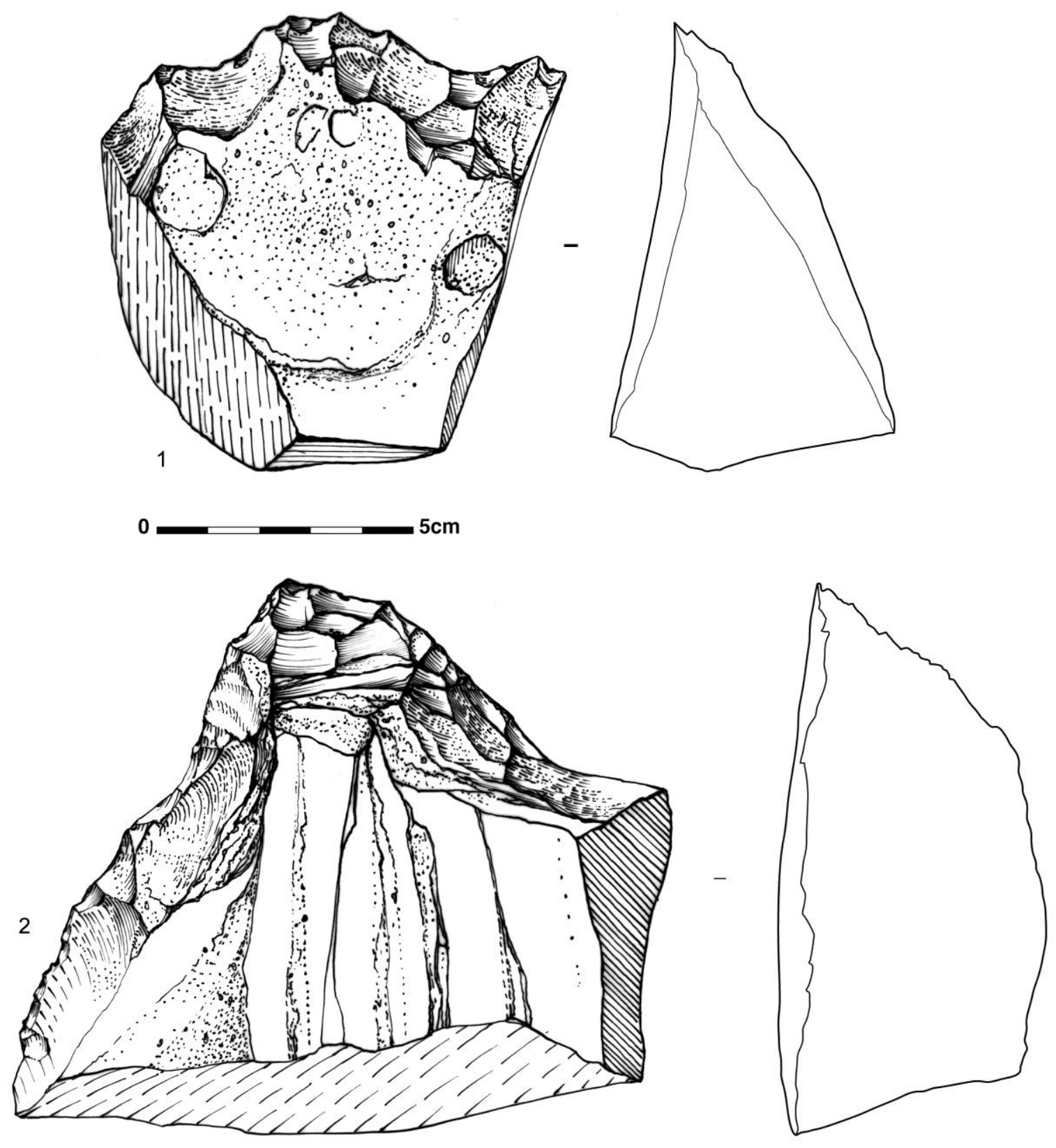


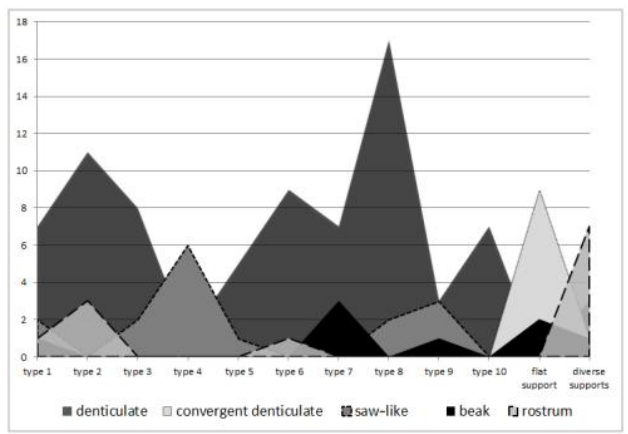




\section{Table 1}

U-Th analysis and dating results for the Yumidong Cave.

\begin{tabular}{|c|c|c|c|c|c|c|c|c|c|c|c|c|c|c|c|c|c|}
\hline Sample Name & $\begin{array}{l}\text { Sampl } \\
\text { e } \\
\text { wt.(g) }\end{array}$ & $\begin{array}{l}\mathbf{U} \\
(\mathbf{p p m} \\
)\end{array}$ & $\pm 2 \square$ & $\begin{array}{l}{ }^{232} \mathrm{~T} \\
\mathrm{~h} \\
\text { (pp } \\
\text { b) }\end{array}$ & $\pm 2 \square$ & $\begin{array}{l}\left({ }^{230} \mathrm{~T}\right. \\
\mathrm{h} / \\
{ }^{232} \mathrm{Th} \\
)\end{array}$ & $\begin{array}{l} \pm 2 \\
\square\end{array}$ & $\begin{array}{l}\left({ }^{230} \mathrm{Th}^{238}\right. \\
\mathrm{U})\end{array}$ & $\pm 2 \square$ & $\begin{array}{l}\left({ }^{234} \mathrm{U} /\right. \\
\left.{ }^{238} \mathrm{U}\right)\end{array}$ & $\pm 2 \square$ & $\begin{array}{l}\text { Uncor } \\
\text { r. Age } \\
\text { (ka) }\end{array}$ & $\pm 2 \square$ & $\begin{array}{l}\text { corr } \\
\text { Age } \\
\text { (ka) }\end{array}$ & $\pm 2 \square$ & $\begin{array}{l}\text { corr. } \\
\text { Initi } \\
\text { al } \\
\left({ }^{234} \mathrm{U} /\right. \\
\left.{ }^{238} \mathrm{U}\right)\end{array}$ & $\pm 2 \square$ \\
\hline 12YMDT4-2-9-tooth & $\begin{array}{r}0.011 \\
39\end{array}$ & $\begin{array}{r}4.000 \\
3\end{array}$ & 0.0022 & 0.81 & $\begin{array}{r}0.00 \\
5\end{array}$ & 1316 & 10 & 0.08827 & $\begin{array}{r}0.0004 \\
3\end{array}$ & $\begin{array}{r}1.187 \\
0\end{array}$ & $\begin{array}{r}0.001 \\
0\end{array}$ & 8.421 & $\begin{array}{r}0.04 \\
3\end{array}$ & $\begin{array}{r}8.41 \\
6\end{array}$ & $\begin{array}{r}0.04 \\
3\end{array}$ & $\begin{array}{r}1.191 \\
5\end{array}$ & $\begin{array}{r}0.001 \\
1\end{array}$ \\
\hline $\begin{array}{l}\text { 12YMDT4-3-54-calc } \\
\text { ite }\end{array}$ & $\begin{array}{r}0.019 \\
9\end{array}$ & $\begin{array}{r}1.767 \\
8\end{array}$ & 0.0012 & $\begin{array}{r}27.0 \\
3\end{array}$ & $\begin{array}{r}0.03 \\
9\end{array}$ & $\begin{array}{r}114.9 \\
7\end{array}$ & $\begin{array}{r}0.4 \\
1\end{array}$ & 0.5794 & 0.0019 & $\begin{array}{r}1.145 \\
2\end{array}$ & $\begin{array}{r}0.000 \\
9\end{array}$ & 75.59 & 0.37 & $\begin{array}{r}75.2 \\
0\end{array}$ & 0.41 & $\begin{array}{r}1.180 \\
4\end{array}$ & $\begin{array}{r}0.001 \\
2\end{array}$ \\
\hline $\begin{array}{l}\text { 12YMDT4-3-54-toot } \\
\text { h }\end{array}$ & $\begin{array}{r}0.009 \\
93\end{array}$ & $\begin{array}{r}43.28 \\
6\end{array}$ & 0.033 & $\begin{array}{r}20.8 \\
7\end{array}$ & $\begin{array}{r}0.08 \\
8\end{array}$ & 3868 & 22 & 0.6147 & 0.0024 & $\begin{array}{r}1.179 \\
9\end{array}$ & $\begin{array}{r}0.001 \\
2\end{array}$ & 78.51 & 0.45 & $\begin{array}{r}78.5 \\
0\end{array}$ & 0.45 & $\begin{array}{r}1.224 \\
6\end{array}$ & $\begin{array}{r}0.001 \\
4\end{array}$ \\
\hline $\begin{array}{l}\text { 12YMDT3-4-68-1-ca } \\
\text { lcite }\end{array}$ & $\begin{array}{r}0.152 \\
21\end{array}$ & $\begin{array}{r}0.330 \\
8\end{array}$ & $\begin{array}{r}0.0001 \\
8\end{array}$ & $\begin{array}{r}509 . \\
0\end{array}$ & 0.9 & 2.12 & 0.0 & 1.0748 & 0.0023 & $\begin{array}{r}1.164 \\
8\end{array}$ & $\begin{array}{r}0.000 \\
8\end{array}$ & 240 & 2 & 198 & 51 & 1.495 & 0.116 \\
\hline $\begin{array}{l}\text { 12YMDT3-4-63-calc } \\
\text { ite }\end{array}$ & $\begin{array}{r}0.019 \\
42\end{array}$ & $\begin{array}{r}0.086 \\
6\end{array}$ & $\begin{array}{r}0.0001 \\
3\end{array}$ & 5.87 & $\begin{array}{r}0.01 \\
3\end{array}$ & 51.53 & 0.4 & 1.1501 & 0.0090 & $\begin{array}{r}1.132 \\
0\end{array}$ & $\begin{array}{r}0.002 \\
9\end{array}$ & 400 & 30 & 398 & 30 & 1.415 & 0.033 \\
\hline
\end{tabular}

(Sample name: 12: sample obtained in 2012; YMD: Yumidong cave site; T3 or T4: test pit; -2, 3 or 4: layer; -\#: unique ID.) 
Table 2

Frequency of tools by volumetric structure.

\begin{tabular}{|c|c|c|c|c|c|c|c|c|c|c|c|c|}
\hline \multicolumn{1}{|c|}{ Volumetric structure } & \multicolumn{4}{c|}{ Category B: Trihedral } \\
structure & Category \\
Category A: Structure with bevel(s) & \multicolumn{3}{c|}{ C: } \\
convergent tools \\
\hline type 1 & type 2 & type 3 & type 4 & type 5 & type 6 & type 7 & type 8 & type 9 & type 10 & type 11 & type 12 & \\
\hline 11 & 8 & 7 & 4 & 6 & 11 & 2 & 15 & 11 & 7 & 3 & 7 & 10 \\
\hline
\end{tabular}

